\title{
Improved age estimates for key Late Quaternary European tephra horizons in the RESET lattice
}

Christopher Bronk Ramsey (a) Paul G. Albert (a), Simon P.E. Blockley (b), Mark Hardiman (b), Rupert A. Housley (b), Christine S. Lane (a), (c), Sharen Lee (a), Ian P. Matthews (b), Victoria C. Smith (a), John Lowe (b)

a Research Laboratory for Archaeology, University of Oxford, Dyson Perrins Building, South Parks Road, Oxford, OX1 3QY, UK

b Department of Geography, Royal Holloway University of London, Egham, Surrey, TW20 0EX, UK

c Department of Geography, The University of Manchester, Arthur Lewis Building, Oxford Road, Manchester, M13 9PL, UK

\begin{abstract}
The research project 'Response of Humans to Abrupt Environmental Transitions' (RESET) used tephra layers to tie together and synchronise the chronologies of stratigraphic records at archaeological and environmental sites. With the increasing importance of tephra as chronological markers in sedimentary sequences, both in this project and more generally, comes a requirement to have good estimates for the absolute age of these volcanic horizons. This paper summarises the chronology of the key tephra in the RESET tephra lattice in the time range 10-60 ka BP, from the existing literature, from papers produced as part of the RESET project, and reanalysis conducted for this paper. The paper outlines the chronological approach taken to the dating of tephra within the RESET project, and the basis for further work, as part of the INTIMATE (INTegrating Ice core MArine and TErrestrial records) initiative. For each of the tephra layers in the lattice, the existing literature is discussed and, where relevant date estimates updated using the latest radiocarbon calibration curves (IntCal13 and Marine13) and methods. Maps show the approximate extent of tephra finds, giving a visual indication of the coverage of the lattice in different time-periods.
\end{abstract}

\section{Keywords}

- Dating;

- Tephrochronology; 
- Radiocarbon;

- Age-Depth modelling;

- Archaeology;

- Quaternary environments

\section{Introduction}

The main strength of tephra layers for studying rapid environmental change is their ability to act as stratigraphic markers across many different records, providing information about the phasing of regional changes around the period of the transition. More generally they allow us to constrain the relative chronologies of different environmental records. However, they also provide a way to assign age to those same marker horizons if direct information on the age of the tephra layers themselves is available. In some cases such ages can be inferred from dates on the eruption event itself, normally through A40r/A39r dating of proximal deposits. More often tephra layers are dated by other indirect dating methods at distal sites.

The past decade has seen considerable progress in the development of chronology quantification, through improved radiocarbon calibration curves (Reimer et al., 2004, Hughen et al., 2004, Reimer et al., 2009 and Reimer et al., 2013), a fully counted Greenland ice-core chronology for this period (Andersen et al., 2006, Rasmussen et al., 2006 and Rasmussen et al., 2014), and refined procedures for age model construction (see for example Blaauw and Christen, 2005, Bronk Ramsey, 2008 and Scholz and Hoffmann, 2011). These advances have implications for assessing the reliability of age estimates assigned to tephra layers and this paper is intended to summarise the chronology of the key late Quaternary European tephra horizons relevant to the objectives of the research project on the Response of Humans to Abrupt Environmental Transitions (RESET) that are in the time range 10-60 ka BP (see Table 1). In cases where radiocarbon is used, as a minimum the radiocarbon dates have been re-calibrated against the latest calibration curve, and where possible the results remodelled using the latest approaches. 
Using tephra layers as a chronological tool has three basic pre-requisites: the ability to locate the tephra in the region of interest, the ability to identify the tephra to a specific eruption by chemical analysis (e.g. Shane, 2000), and the availability of a quantified age estimate for that tephra. The RESET database (Bronk Ramsey et al., 2014b) provides this information for a wide range of tephra layers relevant to Europe and North Africa and this paper is intended to provide a convenient summary. For each of the key tephra layers, a brief description is provided together with a map showing the extent of finds documented within the database and the best estimate of the age of the tephra.

\section{Methodological background}

Most of the information in this paper, is based on the methodologies of referenced papers. The focus here is on the methodology that has been used to update and summarise the age estimates of the tephra layers. For such estimates to be useful, they must be both robust and presented in a way which facilitates further analysis. These two aims do provide some tension. The choices made are largely determined by the wish to feed into the INTIMATE initiative, which has a broader remit for the synchronisation of records from different environments (see in particular: Bronk Ramsey et al., 2014a). Some of the detail given here is not relevant to the specific tephra layers listed, but the methodology has been applied to all tephra layers listed in the 'eruptions' table of the RESET database (Bronk Ramsey et al., $2014 b$ ), and so is given for reference.

\subsection{Time scales}

When applying any dating technique, it is important to consider the underlying time scale. Ideally this would be the astronomical passage of the seasons which defines the annual cycle. In the case of dendrochronology this ideal is approached, and counted ice-core years or lakevarves attempt to achieve the same. In reality, even with these precise methods, there is the chance of errors (due, for example, to gaps and miscounting), and over long timescales these add significant uncertainty. The other timescales that are of primary importance are based on direct physical methods, either radiometric methods with known half-lives, or dosimetric methods which rely on direct scientific measurements. In the end these are tied to SI units of time, and in this sense are absolute. However, there are limitations in all dating techniques, some of which might be systematic and not well understood, and this needs to be kept in mind. 
For all these reasons, ages are always defined against some reference time scale and this needs to be specified alongside an age. The relationship between timescales is something that then becomes critically important when integrating information from different records (Bronk Ramsey et al., 2014a). The most important timescales for the late Quaternary (in no particular order) are: dendrochronology, the absolute timescales afforded by the radiometric methods U234/T230h dating, and the counted ice-core chronology of the Greenland ice-cores (currently GICC05 Andersen et al., 2006, Rasmussen et al., 2006, Rasmussen et al., 2008, Svensson et al., 2006 and Svensson et al., 2008). Built on these are the composite IntCal timescales (for radiocarbon calibration) which use dendrochronology where possible and U234/T230h dating beyond that (IntCal04, Marine04, IntCal09, IntCal13, Marine13: Reimer et al., 2004, Hughen et al., 2004, Reimer et al., 2009 and Reimer et al., 2013). The aim of this paper is to give the chronology of the tephra layers in relation to one of these main timescales, and for reference to choose the timescale in which the tephra is known to greatest precision.

In addition to these long-term timescales there are specific records which are of particular relevance to the high-resolution chronology of tephra horizons within Europe. There are the varve-based chronologies of Holzmaar (Germany; Zolitschka, 1991), Meerfelder Maar (Germany; Brauer et al., 1999; labelled here as 'MFM Varves') and Lago Grande di Monticchio (Italy; Wulf et al., 2004; labelled here as 'LGdM Varves'). In some instances the chronologies are known best relative to these site-specific chronologies.

\subsection{Deposition models}

Although there are several methods to date tephra deposits directly (such as A40r/A39r, A40r/K39, fission track, U238/P206b or U235/P207b), there are many cases where it is difficult to apply them in practice to distal deposits, particularly in the Quaternary. In some instances radiocarbon dating of short-lived organic matter immediately underlying a tephra will give what amounts to a direct date on the eruption. However, such instances are rare, especially for older material, for example dating beyond the practical limits of radiocarbon dating. For these reasons it is frequently necessary to infer ages of tephra layers from measurements made in sedimentary sequences that contain tephra. In order to do this, whatever the dating method (usually radiocarbon, but it could also be Optically Stimulated Luminescence or OSL) it is necessary to use age-depth models. There are a number of methodologies available (see for example Blaauw and Christen, 2005, Bronk Ramsey, 2008, 
Bronk Ramsey, 2009b and Bronk Ramsey and Lee, 2013) but the critical point is that the uncertainties in the interpolation should be included in the final ages of the tephra. This is something that has not always been done in the past (see for example Section 4.17 below).

As part of the RESET project new methods were developed that allow for the production of age-depth models without making assumptions about the constancy of the sedimentation rate (Bronk Ramsey and Lee, 2013) and examples of this approach are given below and in Lee et al. (2013). This new averaging approach allows significant changes in rate of sedimentation to be taken into account, and provides a quantified uncertainty in the interpolation between dated points.

Another approach which has been taken in RESET projects is to link the dates from the same tephra in two related age models. This enables the use of information from more than one age-depth model to determine the date of eruptions, thereby reducing the uncertainties involved (see Section 4.17).

All age-depth models developed for this paper are listed in the supplementary online material.

\subsection{Age uncertainties}

There are various ways in which age uncertainties can be expressed, depending on the field of application and the type of record involved. For many geological dating techniques it is quite common to define $2 \sigma$ error terms that give the equivalent of a $95.4 \%$ probability range. When Bayesian techniques are used it is usual to give the $95.4 \%$ error range, and sometimes in addition the $68.2 \%$ range to indicate the period that is most likely. In ice core and varve chronologies a 'maximum counting error' (MCE) is common, which is intended to give the maximum reasonable variation away from the quoted value. For luminescence techniques the standard uncertainty $(1 \sigma)$ is normally quoted, as is the case for uncalibrated radiocarbon dates.

These differences reflect different traditions and the different uses the dates are being put to. Where the date is the final output and all that is required is a conservative range within which the true date might lie, a 95.4\% range can be useful. However if the result is to be used as input into another calculation, this plurality of conventions is a hindrance. As the aim here is 
to provide useful numbers for further modelling and chronological integration exercises (Bronk Ramsey et al., 2014a), here the mean $(\mu)$ and standard uncertainty $(\sigma)$ are used, with a reference timescale. This does require conversion of published data: where $2 \sigma$ errors are given, these are halved; where 95.4\% ranges only are given, a quarter of the range is taken; where the $68.2 \%$ ranges are given, half the range is taken; where a maximum counting error is defined, this is treated like a $95.4 \%$ range. If there is central value given this is treated as the mean and if the errors are asymmetric, these are averaged.

Another area for complication, is where the timescale itself has a quantified uncertainty (GICC05, Holzmaar Varves, MFM Varves, LGdM Varves). In such cases there are really two different uncertainties in the definition of a tephra age: the first is how well known the date is relative to the reference chronology (this can be as precise as a specific year, or a couple of neighbouring years), and the second how well the chronological scale is defined relative to other more absolute scales. Here GICC05 is treated differently because this is a chronology that covers the entire age range of interest and, partly because it is already synchronised with all of the other ice core data from Greenland and Antarctica, and is therefore de facto a global chronological reference. Where tephra layers have been dated to the GICC05 timescale, only the error relative to that timescale is given. Against other primary counted timescales (Holzmaar Varves, MFM Varves and LGdM Varves) the uncertainty in the timescale itself is also included.

In quite a few instances tephra can be dated by a number of different methods. In these cases, in the summary table only the most precise dates (based on the conventions outlined in the previous paragraph), are given but other estimates are reported in the text.

\section{The tephra lattice}

Table 1 summaries the key tephra layers which comprise the tephra lattice developed as a central part of the RESET project. For each tephra the best estimate of the age of the tephra is given against the timescale which has the highest precision. The age estimates here are taken from published sources, the only modifications being to scale the uncertainties (see Section 2.3 above). In many instances there are several different age estimates for the tephra, sometimes against different timescales. 
In many instances the only way tephra layers can be dated is one by one with specific dated constraints or single age-depth models. However, where several tephra layers can be detected in multiple sites, composite age models can be developed that, if coherent, reduce the age uncertainties. The best example of this is for the period 9-15 ka cal BP where 8 records in 7 locations, together with the regional stratigraphy from the Campanian volcanic field (CVF), can be linked together using 19 different tephra layers with 297 radiocarbon dates, and a Bayesian model run using OxCal v4.2.4 (Bronk Ramsey, 2009a, Bronk Ramsey, 2009b and Bronk Ramsey and Lee, 2013). This yields composite age estimates with reduced error ranges and higher confidence than is the case when only a few isolated radiocarbon dates are available. The model is shown schematically in Fig. 1.

The main records in this model (see Fig. 2) are Kråkenes (Lohne et al., 2013, Core 46), Hässeldala port (Wohlfarth et al., 2006, Core 2), Abernethy Forest (Matthews et al., 2011, using the same selected dates), Holzmaar (Zolitschka et al., 1995), Rotsee (Lotter and Zbinden, 1989), Soppensee (Hajdas et al., 1993 and Lane et al., 2011b), Lake Bled (Lane et al., 2011a), and the proximal sequences of the Campanian volcanic field (CVF) (Smith et al., 2011). In addition the tree ring data of Friedrich et al. (1999) for the LST have been incorporated. Each of the records contains at least two tephra horizons.

In general the main elements of previously-published age models have been re-used, but in all cases variable rigidity (Bronk Ramsey and Lee, 2013) and outlier analysis (Bronk Ramsey, 2009b) were applied to the converged data-set. The whole model was run twice: for Model 1 the suggested litho-stratigraphic boundaries defined by those working on the sediments (in the cases of Kråkenes, Abernethy Forest, and Soppensee) were employed; Model 2 allowed the variation in rigidity to determine significant changes in deposition rate. The latter has the advantage that it is not so subjective, and should allow more easily for changes in deposition rate at points not prescribed. For this reason preference is given to the results of Model 2 but the results of Model 1 are also reported in Table 2 as an indication of the sensitivity of age estimation to specific model choice. Overall the precision of the two models is on average the same, though the errors are slightly different for each tephra. There are no significant differences between the models. The full Model 2 OxCal code is given in Appendix A.1.

The model output provides us with age estimates for individual tephra layers (Table 2). Because all of the age estimates can be constrained by common stratigraphical controls, the 
age uncertainties are not totally independent. This can be quantified by looking at the correlation coefficients between tephra age estimates. Table 3 shows the matrix of Pearson product-moment correlation coefficients for the date estimates. As can be seen, very few of the dates are highly correlated, the pairs with the highest coefficients being: BorrobolPenifiler (0.33), PP-Vedde (0.86), Fondi di Baia - Sartania 1 (0.44) and Pigna San Nicola St Martino (0.46). Of these only the first two are really important for the RESET tephra lattice.

The model can also be used to check the likely order of the tephra layers in the lattice as shown in Table 4. From this it can be seen that the order of La Pigna 1 and the LST is uncertain as is the relative order of the Pigna San Nicola and the VKT. This information is useful when comparing the ages of tephra layers that are not found within the same sequences, therefore precluding a direct assessment of the relative stratigraphic order.

\section{Tephra summaries}

This section of the paper focusses on each of the main lattice tephra layers in turn, provides a brief description of the significance of the tephra, and gives more detail on the existing age estimates including revised assessments based on re-analysis of the existing data.

Many of the Italian tephra layers included in the lattice are correlated to layers found within the Lago Grande di Monticchio (LGdM) stratotype, in Southern Italy, and we include their equivalent "TM" codes from Wulf et al., 2004, Wulf et al., 2007 and Wulf et al., 2012 in Tables 1 and 7. The varved sediment sequence from LGdM is presently the most complete stratified archive of Italian tephra deposits, recording over 350 tephra layers within sediments spanning the Last Glacial cycle (Wulf et al., 2004, Wulf et al., 2007 and Wulf et al., 2012). Further compositional analysis of some of the LGdM tephra layers within the RESET project has updated earlier correlations (for example TM-11, Albert et al., 2013) - these are highlighted in the following descriptions where appropriate.

Fig. 3, Fig. 4 and Fig. 5 provide maps of Europe that reveal the overall distribution of finds of the tephra layers documented in the RESET database. In part these reflect past research intensity and the availability of sampling localities. However, while they cannot be taken as plots of the original distribution of tephra from the associated eruptions, they do give some 
indication of the likely utility of these tephra for linking records in environmental or archaeological contexts.

\subsection{Saksunarvatn}

This tephra is from an ultra-Plinian eruption of the Grimsvotn volcano in Iceland (Thordarson and Larsen, 2007). A tephra with similar properties is found in Greenland (Rasmussen et al., 2006) and across North-Eastern Europe, thus providing a useful early Holocene marker horizon (Wastegård et al., 2001, Dugmore and Newton, 1997, Andrews et al., 2002, PyneO'Donnell, 2007, Birks et al., 1996, Davies et al., 2012, Lind and Wastegård, 2011 and Bramham-Law et al., 2013; Fig. 3).

In Greenland it has been given an age of 10,347 \pm 89 b2k (GICC05 Rasmussen et al., 2006; maximum counting error quoted). A precise radiocarbon date for the tephra has been provided by the Bayesian model of Lohne et al. (2013) on the site of Kråkenes where they give an age estimate of $10,210 \pm 35$ cal BP $(\mu \pm \sigma$; IntCal09). A slightly different version of this model (the main difference being the use of model averaging) has been incorporated into the overall Bayesian model for the period described above in Section 3, which uses the new IntCal13 calibration curve. This provides an updated estimate of 10,257-10,056 cal BP (95\%; IntCal13) or $10,176 \pm 49(\mu \pm \sigma ;$ IntCal13).

It should be noted that some have questioned the correlation between the Saksunarvatn in Europe and in Greenland (Davies et al., 2012 and Bramham-Law et al., 2013).

\subsection{Askja-S tephra}

This tephra is from an ultra-Plinian eruption of the Askja volcanic centre in Iceland. It has very widespread distribution (Davies et al., 2003, Pilcher et al., 2005, Turney et al., 2006, Lind and Wastegård, 2011, Lane et al., 2011b and Lane et al., 2012b) and provides a useful marker early in the Holocene and so this is potentially an important marker layer for understanding the preboreal oscillation (Wohlfarth et al., 2006).

The tephra has been dated using Bayesian modelling by Wohlfarth et al. (2006) using a number of different methods. Their most robust model (B) gives a 95\% range of 11,050 10,570 cal BP using IntCal04. This has been updated using IntCal13, and using the methods described in Section 2.2. The model employed uses the same data, assuming, as the original 
paper did, that the Askja is between 2 and $3 \mathrm{~cm}$ above the highest radiocarbon date in the sequence from Hässeldala port. The model uses rigidity averaging and outlier analysis. To check if the new methodology was comparable we ran the model first using IntCal04 which gave an error range of $11,175-10,608$ at $95.4 \%$ or $10,923 \pm 157$ ( $\mu \pm \sigma$; IntCal04) which is similar to (but slightly wider than) the modelled result given by Wohlfarth et al. (2006). This was then incorporated into the main model described above in Section 3 which also uses constraints on the Askja-S from Soppensee ( Lane et al., 2011b). As reported in Table 2 this gives an error range of $10,956-10,716$ cal BP $(95 \%$; IntCal13) or $10,830 \pm 57(\mu \pm \sigma$; IntCal13). This is currently the best estimate for the date of this tephra.

Major element data is available for this tephra (Davies et al., 2003, Pilcher et al., 2005, Turney et al., 2006, Lind and Wastegård, 2011, Lane et al., 2011b and Lane et al., 2012b).

\subsection{Ulmener Maar tephra}

This tephra, from a phreatomagmatic eruption in the Eifel volcanic field, Germany, has been found in sites in western Germany, and comes at an interesting point in the climatic succession where radiocarbon dating does not have high resolution.

The UMT has been varve dated to 11,000 varve yrs BP from Holzmaar (Zolitschka et al., 1995). AMS radiocarbon dates of the UMT in Holzmaar range between 9,515 \pm 75 and 9,650 \pm 85 C14 years BP (Hajdas et al., 1995), which agrees with an age of 9,610 $\pm 40 \mathrm{C} 14$ years BP from MFM sediments (Endres, 1997). The Holzmaar sequence has been incorporated into the overall Bayesian model for the period which gives an age estimate of 11,400-10,907 cal BP (95\%; IntCal13) or 11,096 \pm 117 ( $\mu \pm \sigma$; IntCal13).

\subsection{AF555}

This is a rhyolitic ash layer only found distally within a single site (Abernethy Forest, Scotland), though from its chemical data it is most likely from Katla (Matthews et al., 2011). Given that its source must be in Iceland, its extent must be considerable and the AF 555 has the potential to constrain the onset of Holocene warming across Europe as, in Abernethy Forest, it is deposited after the warming has begun and around the point that mean July temperatures at this site reach $12^{\circ}$. 
The best age estimate for this is that provided by Matthews et al. (2011) with a Bayesian age model giving a range between 11,790-11,200 cal ka BP (IntCal09). Here, this model is updated within the overall model for the period, using IntCal13 to come up with a revised, and slightly tighter age estimate of $11,721-11,231 \mathrm{cal}$ BP (95\%; IntCal13) or 11,462 $\pm 122(\mu$ $\pm \sigma$; IntCal13) which is now the best estimate for the age of this tephra.

\subsection{Pomici Principali (TM-7b)}

This is a Plinian eruption of the Campanian volcanic field, with tephra found in marine and terrestrial locations to the East of this (see Fig. 3).

Smith et al. (2011) obtained an age for the large PP eruption of 12,158-11,915 cal BP (IntCa109) using the single published radiocarbon measurement (12,930-11,978 cal BP; calibrated date) from Di Vito et al. (2008) and data from Lake Bled (Lane et al., 2011a) which was imported as a prior into an OxCal model. The new combined model for the period incorporates all of the relevant dates using IntCal13 to give an age estimate of 12,091-11,850 cal BP (95\%; IntCal13) or 11,999 $\pm 52(\mu \pm \sigma$; IntCal13) which is now the best estimate for the age of this tephra.

\subsection{Vedde Ash}

This is a bi-modal rhyolitic and basaltic ash layer from an ultra-Plinian eruption that is most likely from Katla, Iceland. It is particularly important within the tephra lattice because of its very wide distribution across Europe (Norddahl and Haflidason, 1992, Thordarson and Larsen, 2007, Larsen, 2010, Lane et al., 2012a, Tomlinson et al., 2012c, Birks et al., 1996, Björck and Wastegård, 1999, Blockley et al., 2007, Davies et al., 2001, Davies et al., 2005, Lane et al., 2011a, Lane et al., 2011b, Lane et al., 2012b, Lowe and Turney, 1997, Matthews et al., 2011, Pilcher et al., 2005, Ranner et al., 2005, Schoning et al., 2001, Turney et al., 1997, Turney et al., 2001, Turney et al., 2006, Wastegård et al., 1998 and Wastegård et al., 2000) as can be seen in Fig. 3. The tephra has recently been shown to be able to differentiate between the timings of abrupt climate change within the Younger Dryas chronozone (Lane et al., 2013).

The tephra has been detected in Greenland ice cores and dated in ice-core years to $12,171 \pm$ 114 yr b2k (GICC05 Rasmussen et al., 2006,; maximum counting error quoted). It has also 
been dated to NGRIP SS09 11,985-11,988 ice core yr BP. Norddahl and Haflidason (1992) have suggested that the Skogar tephra (northern Iceland) is a more local correlative of the Vedde Ash, which shares the chemical compositional range (Lane et al., 2012b). The combined age model which draws on data from Kråkenes, Abernethy, Soppensee, Rotsee and Bled, provides a new estimate of 12,102-11,914 cal BP (95\%; IntCal13) or 12,023 $\pm 43(\mu \pm$ $\sigma$; IntCal13) which is in reasonable agreement with the GICC05 date.

\subsection{Soccavo 1}

This sub-Plinian eruption from the Campanian volcanic field (CVF), gave tephra which can be found in Italy and surrounding marine deposits (Di Vito et al., 1999, Smith et al., 2011 and Albert et al., 2012).

Charcoal in a palaeosol underlying Soccavo 1 tephra gives a C14 age of 10,330 \pm 50 yr BP (CAMS-38438 Di Vito et al., 1999) which calibrates to 12,390-11,990 cal BP (95.4\%; IntCal09) or 12,395-11,975 cal BP (95.4\%; IntCal13). This date has been incorporated, along with the CVF proximal sequence (Smith et al., 2011) into the overall Bayesian model for the period, giving a date of 12,391-12,017 cal BP (95\%; IntCal13) or 12,198 $\pm 112(\mu \pm \sigma$; IntCal13) which is now the best estimate for the date of this tephra.

\subsection{Laacher See Tephra (LST)}

The LST is a very important tephra for northern Europe with wide coverage (see Fig. 4). The tephra comes from a phreato-Plinian eruption that occurred in the eastern Eifel volcanic field, Germany. The dispersal direction changed throughout the eruption dispersing tephra all around the volcano and the distribution of this tephra has been studied in great detail both in its own right and as an important constraint for the end of the Lateglacial Interstadial (van den Bogaard and Schmincke, 1985, Riede and Wheeler, 2009, Riede et al., 2011, Lane et al., 2011b, Turney et al., 2006, Finsinger et al., 2008, Lane et al., 2012b and Housley et al., 2013).

The eruption has been dated to the late Allerød at 12,880 \pm 40 varve years BP (Brauer et al., 1999), or 12,900 \pm 560 years BP by A40r/A39r dating (van den Bogaard, 1995). It has also been dated by radiocarbon dating to $11,063 \pm 12 \mathrm{BP}$ which calibrates to $13,010-13,200 \mathrm{cal}$ BP (95.4\%; IntCa198; Friedrich et al., 1999). The overall Bayesian model for the period 
which included the tree ring data of Friedrich et al. (1999), and has constraints from Holzmaar, Soppensee and Rotsee gives a calibrated radiocarbon age estimate of 12,97912,889 cal BP (95\%; IntCal13) or 12,937 \pm 23 ( $\mu \pm \sigma$; IntCal13), in good agreement with the other estimates.

\subsection{Penifiler tephra}

This is a tephra which is only known distally, but from its chemical composition (Davies et al., 2003, Pyne-O'Donnell, 2007, Pyne-O'Donnell et al., 2008 and Matthews et al., 2011) and geographical distribution, is most likely from Iceland. In Scotland the tephra occurs closely associated with a climatic oscillation which, chronologically speaking, is broadly consistent with the Older Dryas or GI-1d cold oscillation. Matthews et al. (2011) suggest this tephra occurs on the transition from cold to warm mean July temperatures.

This has been dated using a Bayesian age model by Matthews et al. (2011) to 14.08-13.68 cal ka BP (95.4\% range; IntCa109). Here the age estimate is updated using the new data from IntCal13 and constrained within the overall tephra lattice. The eruption at Hässeldala port with a Borrobol-like chemistry (Wohlfarth et al., 2006) is assumed to be the Penifiler; this cannot be proven, because there seem to be a number of similar eruptions around the same time, but makes sense both climatically and chronologically (Matthews et al., 2011 and Davies et al., 2012). This gives us an age estimate of 14,063-13,808 cal BP (95\%; IntCal13) or $13,939 \pm 66(\mu \pm \sigma$; IntCal13) which is now the best estimate for the age of this tephra.

\subsection{Borrobol}

This is a tephra which is only known distally, but as with the Penifiler tephra, with which it can be confused, its chemical composition (Turney et al., 1997, Turney et al., 2001, PyneO'Donnell, 2007, Ranner et al., 2005 and Matthews et al., 2011) and distribution pattern imply that it is from Iceland. The layer in Scotland occurs toward the end of the early interstadial after peak mean July temperatures have already been achieved (Matthews et al., 2011). As with the Penifiler tephra, there is some uncertainty over whether the tephra layers identified as the 'Borrobol' at different locations are all from the same event (Davies et al., 2012 and Pyne-O'Donnell et al., 2008). 
This has been dated using a Bayesian age model for the Abernethy record by Matthews et al. (2011) to 14.14-13.95 cal ka BP (95.4\% range; IntCal09) with a previous estimate by Turney et al. (1997) of c.14.4 cal ka BP. The suggestion of Davies et al. (2004) that there are two eruptions has been revised by Matthews et al. (2011). The age estimate is updated using the new integrated model. This gives an age estimate of 14,190-14,003 cal BP (95\%; IntCal13) or $14,098 \pm 47(\mu \pm \sigma$; IntCal13) which is now the best estimate for the age of this tephra.

\subsection{Neapolitan Yellow Tuff (NYT; TM-8)}

The NYT derives from an ultra-Plinian eruption from the Campanian volcanic field. It is subdivided into upper and lower members (see context field of the RESET database; Bronk Ramsey et al., 2014b). The lower member is more likely to be significant distally and is recorded at Lago Grande di Monticchio, however the upper member may also be represented at some localities. The tephra is found extensively in central southern Europe with one occurrence North of the Alps (Bourne et al., 2010, Lane et al., 2011a, Magny et al., 2006, Pappalardo et al., 1999, Schmidt et al., 2002, Tomlinson et al., 2012a, Di Vito et al., 2008, Wulf et al., 2004, Wulf et al., 2007, Wulf et al., 2008, Zanchetta et al., 2008 and Lane et al., forthcoming, See Fig. 4).

The best current age estimate is c. $12,100 \pm 170 \mathrm{C} 14$ yr BP which is $14,870-13,510$ cal BP (95\%; IntCal04) (Siani et al., 2004). The varve age for TM-8 in LGdM is $14,120 \pm 710 \mathrm{yr}$ BP (Wulf et al., 2004 and Wulf et al., 2008). However there are also radiocarbon dates from under the tephra layer which suggest younger dates (see for example Alessio et al., 1971 and Scandone et al., 1991), while K-Ar dates (Cassignol and Gillot, 1982) and A40r/A39r dates, the most precise date estimate being $14,900 \pm 400 \mathrm{BP}$ at $2 \sigma$ ( Deino et al., 2004), suggest slightly older dates. Working on the principle that if anything radiocarbon dates are likely to be underestimates (due to more recent contamination), and Ar dates over-estimates, the date proposed by Siani et al. (2004) seems most likely to be secure, however, there is clearly a need for more new radiocarbon data.

There is not much that can be done to improve on the absolute age of this eruption, on the basis of the available evidence. With the new calibration curve the terrestrial C14 age of $12,100 \pm 170$, now dates to a range of 14,717-13,563 cal BP (95.4\%; IntCal13) or 14,066 \pm $293(\mu \pm \sigma$; IntCal13). The marine measurement from MD90917, which is $12,660 \pm 110($ Siani et al., 2000, date is given as 12,260 \pm 110 but 'corrected' by 400 years), along with the 
$\Delta \mathrm{R}$ for the Adriatic Sea of $54 \pm 30$ ( Siani et al., 2000) now calibrates to a range of $14,681-$ 13,816 cal BP (95.4\%; Marine13) or $14181 \pm 222(\mu \pm \sigma$; Marine13). Using a combination of these two calibrated dates, which are in agreement, gives a combined estimate range of $14,433-13,795$ cal BP $(95 \%)$ or $14,085 \pm 154$ cal BP $(\mu \pm \sigma)$. This is the prior used for the NYT in the integrated Bayesian model (see Section 3). The posterior estimate from the model is a range of 14,588-13,884 cal BP (95\%; IntCal13) or 14,194 $\pm 172(\mu \pm \sigma$; IntCal13) which is the best estimate, including other constraints. Note the new calibration curve has made quite a large difference here, and the radiocarbon dates are further from the A40r/A39r date of Deino et al. (2004), but closer to the LGdM date of Wulf et al., 2004 and Wulf et al., 2008 .

\subsection{Biancavilla Ignimbrite (Y-1)}

This tephra derives from a Plinian eruption of Etna, southern Italy, and is widely found in marine cores from the Mediterranean (see Fig. 4). TM-11 has been confused with the Biancavilla-Montalto Ignimbrite and thus sometimes labelled as the Y-1. However, the tephra layers are shown to be geochemically distinct (Albert et al., 2013).

Albert et al. (2013) discuss the chronology of this sequence of eruptions in detail and estimate the date of the Biancavilla-Montalto Ignimbrite to be 17,670-16,965 cal BP (95\% IntCal09) on the basis of Siani et al. (2001). This has been updated on the basis of IntCal13 to be 17,605-17,065 (95\%; IntCal13) or 17,335 $\pm 139(\mu \pm \sigma$; IntCal13) on the same basis. See Appendix A.3 for calibration code for this tephra layer, the TM-11 and Verdoline. The new chronology for the sequence at Etna is given in Table 5.

\subsection{TM-11}

This tephra derives from a Plinian eruption of Etna and is found in marine and lacustrine deposits. It has been confused with the Biancavilla-Montalto Ignimbrite and thus sometimes labelled as the Y-1 (Albert et al., 2013).

TM-11 has a varve age of 16,440 $\pm 820 \mathrm{yr}$ BP in Lago Grande di Monticchio (Wulf et al., 2004 and Wulf et al., 2008). The relationship of this tephra to the Verdoline has been used by Albert et al. (2013) to derive an age of 17,640-18,324 cal BP (95\% IntCal09). Details are 
given in Appendix A.3. This has updated on the basis of IntCal13 to be 18,349-17,870 (95\%; IntCal13) or $18,106 \pm 120(\mu \pm \sigma$; IntCal13).

\subsection{Verdoline (TM-12)}

This tephra comes from a sub-Plinian eruption of Somma Vesuvius and has a fairly limited extent in the Italian peninsula and Adriatic (Andronico et al., 1995, Siani et al., 2004, Wulf et al., 2004 and Wulf et al., 2007).

An approximate age of 19,145 \pm 260 cal BP (Marine04) is given by Siani et al. (2004, identified as L8 in MD90-917) from a radiocarbon date on mono-specific planktonic

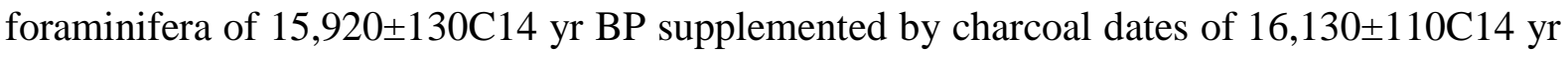
BP (Andronico et al., 1995 and Siani et al., 2001) and 15,870 \pm 90 reported in Siani et al. (2001, supplemental information. The varve age for TM-12 from Lago Grande di Monticchio is 17,560 $\pm 880 \mathrm{yr} \mathrm{BP}$ (Wulf et al., 2004 and Wulf et al., 2008).

Here the same data available to Siani et al. (2004) is reanalysed in the light of the new IntCal13 calibration dataset. The marine radiocarbon date from MD90-917 is 16,320 $\pm 130 \mathrm{C} 14$ $\mathrm{yr} \mathrm{BP}$ in uncorrected form, which can be used with the $\Delta \mathrm{R}$ for the Adriatic Sea of $54 \pm 30$ ( Siani et al., 2000). This is combined with the terrestrial dates from Siani et al. (2001) to get a calibration of 19,435-19,025 cal BP (95.4\%; IntCal13/Marine13) or 19,226 $\pm 104(\mu \pm \sigma$; IntCal13/Marine13). The details of the combination are given in Appendix A.3. This is the best current estimate for the absolute date of this eruption.

\subsection{Cape Riva (Y-2)}

This is an explosive Plinian eruption from the Santorini volcanic centre (Druitt et al., 1989 and Vespa et al., 2006), with widespread deposits in the Eastern Mediterranean (see Fig. 5). This tephra has been correlated to the widespread Y-2 marine tephra horizon.

Lee et al. (2013) have used a Bayesian model to date the eruption giving a $68 \%$ range of 22,157-21,567 cal BP. This is based on data from the Megali Limi basin (Levos, Greece; Margari et al., 2009), Tenaghi Philippon (Muller et al., 2011), Lake Iznik (Turkey; Roeser et al., 2012) and the Philippi peat basin (Greece; Seymour et al., 2004). The eruption was previously dated, by an AMS radiocarbon date on single charcoal from a layer covered by

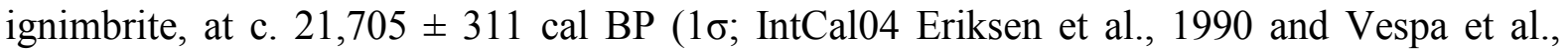


2006) which is in good agreement. Here the model of Lee et al. (2013) is updated to include outlier analysis, take account of the new data in IntCal13, and the new link between Tenaghi Philippon and the Y-3 (See Section 4.17 and Albert et al., 2014). The details of this combined model are given in Appendix A.4. The model gives a best estimate date for the Cape Riva (Y2) tephra of 22,373-21,888 cal BP (68\% range), 22,523-21,308 cal BP (95\% range) or $22,024 \pm 321(\mu \pm \sigma ;$ IntCal13 $)$.

\subsection{Pomici di Base (TM-13)}

This is a Plinian eruption from the Somma-Vesuvius volcanic centre (Andronico et al., 1995 and Siani et al., 2004) with tephra dispersal similar to that of the Verdoline eruption (see Fig. $5)$.

Pomici di Base is dated to c. 18,220 $\pm 140 \mathrm{C} 14$ yr BP (22,220-21,405 cal BP, IntCal09; Siani et al., 2004) by a single radiocarbon date (GifA 98095). Alternatively, the varve age for TM13 from Lago Grande di Monticchio is 19,280 \pm 960 yr BP (Wulf et al., 2004 and Wulf et al., 2008). Recalibrating the terrestrial radiocarbon date gives us a range of 22,417-21,754 cal BP (95\%; IntCal13) or 22,0181 $\pm 173 \mathrm{cal} \mathrm{BP}(\mu \pm \sigma$; IntCal13) which is now the best estimate for the age of this tephra.

\subsection{Y-3 Tephra (TM-15)}

This tephra is from a major Plinian eruption from the Campanian volcanic field with widespread tephra dispersal (Fig. 5; Buccheri et al., 2002b, Buccheri et al., 2002a, Pappalardo et al., 1999, Di Vito et al., 2008, Wulf et al., 2004, Wulf et al., 2008, Zanchetta et al., 2008 and Albert et al., 2014). Di Vito et al. (2008) argue this is the distal correlate of the VRa products in the Campanian volcanic field, though this is shown not be the case by Albert et al. (2014).

The tephra is dated in the Tyrrhenian Sea to c. $25,570 \pm 110$ C14 yr BP in marine core C45 [30,530 $\pm 160 \mathrm{yr}$ cal BP; Marine09] and c. 26,030 $\pm 150 \mathrm{C} 14 \mathrm{yr}$ BP [30,820 $\pm 170 \mathrm{yr}$ cal BP; Marine09] in core C106 (Buccheri et al., 2002a and Buccheri et al., 2002b), on foraminifera sampled 3 and $4 \mathrm{~cm}$ below the layer.

This age estimate of the eruption is reconsidered here. For the Tyrrhenian Sea, Siani et al. (2000) report four estimates for $\Delta \mathrm{R}$ which average to give $70 \pm 48$. These are used together 
with the Marine13 calibration and a Bayesian model to remodel the data from both the $\mathrm{C} 106$ and $\mathrm{C} 45$ cores together. For the age depth model event-free (EF) depth scales are used which takes into account the depositions of the main tephra layers (see Table 6). The online supplement Appendix A.5 gives the full code for this model which allows us to make full use of the uncertainty in deposition rate and when interpolating from the radiocarbon dates. This gives us a range of 29,541-28,618 cal BP (95\%; Marine13) or 29,096 \pm 246 cal BP $(\mu \pm \sigma$; Marine13).

However, in addition to these data Albert et al. (2014) show that the Y-3 is identified at a depth of $9.7 \mathrm{~m}$ in the sequence at Tenaghi Philippon. This information can be used to link the marine model given in Appendix A.5 with the model for the Y-2 from Lee et al. (2013), giving a combined model that provides dates for both the Y-2 and the Y-3 (see Appendix A.4). This combined model gives a best estimate date for the Y-3 tephra of 29,248-28,895 cal BP (68\% range), $29,410-28,710$ cal BP (95\% range) or $29,059 \pm 178(\mu \pm \sigma$; IntCal13/Marine13). This is the best current estimate of the age of this tephra.

\subsection{Codola (TM-16b)}

The Codola tephra is from a Plinian eruption of the Somma-Vesuvius volcanic centre (Andronico et al., 1995, Siani et al., 2004 and Tomlinson et al., in this volume).

The best age estimate is given by Di Vito et al. (2008) which is 30,680 \pm 780 ( $1 \sigma$ equivalent, or $\pm 15602 \sigma$ equivalent). This is based on extrapolation between the varve ages for TM-16a and TM-16b (top and base) of 30,240 \pm 1510 and 31,120 $\pm 1560 \mathrm{yr}$ BP in Lago Grande di Monticchio ( Wulf et al., 2007). It has also been dated to c. $25,100 \pm 400 \mathrm{C} 14 \mathrm{yr}$ BP ( Alessio et al., 1974), which calibrates to 30,320-28,370 cal BP (95\%; IntCal13) or 29,250 4480 cal BP $(\mu \pm \sigma ;$ IntCal13).

\subsection{Campanian Ignimbrite (Y-5; TM-18)}

The Campanian Ignimbrite (CI) is from an ultra-Plinian eruption from the Campanian volcanic field, and is the largest eruption in Europe of the period of study (see Fig. 5; Pappalardo et al., 1999, Di Vito et al., 2008, Zanchetta et al., 2008 and Pyle et al., 2006). The CI eruption dispersed $250-300 \mathrm{~km} 3$ of tephra or 104-125 km3 of magma (dense rock 
equivalent) over 3.7 million $\mathrm{km} 2$ (Costa et al., 2012) forming one of the most widespread tephra units in Europe.

The eruption is well dated by single crystal A40r/A39r dates from proximal deposits to

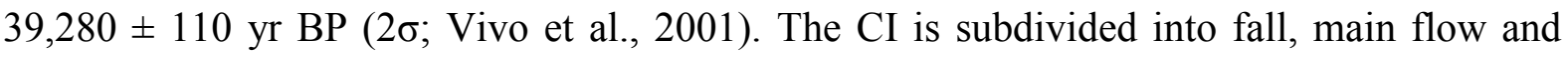
upper flow (see context field in the RESET database). Investigation of distal CI deposits within the RESET project have shown that the upper flow is more widely distributed than previously thought. The fall and main flow components are both represented at Lago Grande di Monticchio ( Tomlinson et al., 2012a). Y-5 is the marine equivalent marker layer. This tephra is near the limit of radiocarbon dating but has also been dated using rigorous ABOX radiocarbon methods on charcoal which is found beneath the tephra ( Wood et al., 2012). These data have been modelled using IntCal13 (see Appendix A.6) to estimate the date of the overlying tephra and obtain a date of 39,490-38,430 cal BP (95\%; IntCal13) or 38,950 \pm 270 cal BP $(\mu \pm \sigma ;$ IntCal13) which is in agreement with the A40r/A39r date.

\subsection{Green Tuff (Y-6)}

This tephra is from an ultra-Plinian eruption of Pantelleria in the Sicily Channel (Cornette et al., 1983, Mahood and Hildreth, 1986 and Civetta et al., 1988).

The tephra was originally K/Ar dated between c.47-51 ka by Cornette et al. (1983), c.45-50 ka by Mahood and Hildreth (1986) and c.47-50 ka by Civetta et al. (1988). More recently the Green Tuff (Y-6) has been reanalysed via the A40r/A39r technique to $45.7 \pm 1 \mathrm{ka}(2 \sigma$; Scaillet et al., 2013) which is taken to be the best estimate here.

\subsection{Nisyros Upper Pumice}

The Nisyros Upper Pumice (NUP) is a sub-Plinian eruption from Nisyros in the Hellenic Arc volcanic region. None-the-less the tephra is found widely in the Aegean region (see Fig. 5; Limburg and Varekamp, 1991, Hardiman, 1999 and Pyle and Margari, 2009).

Tomlinson et al. (2012b) suggest an age of c.47 ka based on their review of the dating, following Limburg and Varekamp (1991). Alternatively, Pyle and Margari (2009) give c. 46 \pm 5.7 ka. However, Karkanas et al. (2014), present stratigraphic evidence from Theopetra Cave in Greece, which shows that the NUP pre-dates the Green Tuff (Y-6) and deduce an age 
which is greater than $50.4 \mathrm{ka}$ cal BP. The existing ages, based mainly on radiocarbon dating close to the limits of the method, are therefore under-estimates of the tephra age.

\subsection{Mount Epomeo Green Tuff (MEGT; TM-19)}

The MEGT was produced by an ultra-Plinian caldera forming eruption of the volcanic island of Ischia. Ischia is located in the bay of Naples, Italy and is the most westerly volcano of the Phlegraean Volcanic District (Vezzoli, 1988 and Brown et al., 2008).

The proximal age of the MEGT was determined using the K/Ar method at about 52-58 ka (Gillot et al., 1982). MEGT was correlated to the distal TM-19 tephra at Monticchio (Wulf et al., 2004) and this layer is directly dated using A40r/A39r to $55 \pm 2 \mathrm{ka}(1 \sigma)$ ( Watts et al., 1996). The A40r/A39r age of TM-19 indicates that its 60,060 \pm 3000 yrs BP varve age ( Wulf et al., 2012) may present a slight overestimate. Tomlinson et al. (2014) demonstrate that the prominent distal Y-7 marker tephra correlates to the MEGT eruption and a A40r/A39r age of $56 \pm 4 \mathrm{ka}(1 \sigma)$ for this tephra recorded on Stromboli Island, southern Tyrrhenian Sea ( Kraml, 1997), supports the TM-19 A40r/A39r age. The diagnostic major and trace element glass chemistry of the MEGT eruption and distal equivalents are presented in Tomlinson et al. (2014) and it is recommended that the A40r/A39r age of TM-19 ( Watts et al., 1996) provides the best age estimate for the MEGT eruption.

\section{Conclusion}

Table 7 provides an update on the estimated ages of key late Quaternary tephra layers based on the research carried out in the RESET project and through other initiatives such as the development of the IntCat13 and Marine13 calibration curves (Reimer et al., 2013). This provides the best assessment of individual tephra ages that can made on the basis of current information and procedures, and hence provides a working lattice-age-model until matters can be further improved. However, this chronology is not an end in itself; it is only important because these tephra horizons are an important tool in the integration of chronological information from a whole range of records (for example, forming a key element in the INTIMATE database and chronology integration tool: Bronk Ramsey et al., 2014a).

There is clearly more that needs to be done on a number of fronts. The research reported here shows the value of correlating tephra layers, especially when they can be related to key 
sequences such as that at Lago Grande di Monticchio, and the Greenland Ice cores. There remain many tephra layers, including those not on the list above which have potential utility as chronological markers but whose identification in distal deposits is problematic often due to indistinct chemical compositions. Despite the chronological advances made over the last few years there are also some important tephra layers which have poor chronological constraint: just from those listed in Table 7, these include the Neapolitan Yellow Tuff (NYT), Codola (C-10) and the Nisyros Upper Pumice (NUP).

The RESET project has demonstrated a number of different ways that the tephra lattice can be directly used to improve our understanding of past processes. One type of application is where tighter age control can be gained by cross correlation between environmental records and the layer-counted ice cores (see, for example, Matthews et al., 2011), or annually varved lake sediments (Lane et al., 2013). Another is the use of tephra layers as widespread markers which can help to understand processes of change, such as the spread of anatomically modern humans into Europe and the regional extinction of Neanderthals (Lowe et al., 2012). Tephra horizons can also be used as an independent test of dating techniques and their associated age models (see, for example, Karkanas et al., 2014).

The updated age estimates for key tephra layers reported here will have two main applications. In the first instance, those sites where these tephra layers are found can now be dated to higher precision against the reference timescales of IntCal13 and GICC05. Perhaps equally importantly, other sites which are dated by radiocarbon alone can now be more accurately aligned to those records where tephra are present. In addition, this paper presents a methodology for the integration of information from multiple records, where tephra layers provide an inter-correlated lattice that can be used by others to further refine and extend the chronology of the late Quaternary.

\section{Acknowledgements}

The research and developments behind this paper were conducted in support of a NERCfunded project on Response of Humans to Abrupt Environmental Transitions (NE/E015670/1). The authors would like to express their thanks to NERC for funding and to all the other members of the RESET team, who contributed in different ways to the construction of the tephra lattice. This publication forms Royal Holloway and OXford TephrochrOnology Research network (RHOXTOR) contribution RHOX/039. 


\section{REFERENCES}

Albert, P. G., Hardiman, M., Keller, J., Tomlinson, E. L., Bourne, A. J., Smith, V., Wulf, S., Zanchetta, G., Sulpizio, R., Mller, U. C., Pross, J., Ottolini, L., Matthews, I. P., Blockley, S. P., Menzies, M. A., 2014. Revisiting the Y-3 tephrostratigraphic marker: a new diagnostic glass geochemistry, age estimate, and details on it climatostratigraphic context. Quaternary Science Reviews in review; this volume.

Albert, P. G., Tomlinson, E. L., Lane, C. S., Wulf, S., Smith, V. C., Coltelli, M., Keller, J., Castro, L. D., Manning, C. J., Müller, W., Menzies, M. A., 2013. Late glacial explosive activity on Mount Etna: Implications for proximal-distal tephra correlations and the synchronisation of Mediterranean archives. Journal of Volcanology and Geothermal Research 265 (0), $9-26$.

Albert, P. G., Tomlinson, E. L., Smith, V. C., Roberto, D. A., Todman, A., Rosi, M., Marani, M., Muller, W., Menzies, M. A., 2012. Marine-continental tephra correlations: Volcanic glass geochemistry from the Marsili Basin and the Aeolian Islands, Southern Tyrrhenian Sea, Italy. Journal of Volcanology and Geothermal Research 229-230, 74-94.

Alessio, M., Bella, F., Improta, S., 1974. University of Rome Carbon-14 Dates XII. Radiocarbon 16 (3), 358-367.

Alessio, M., Bella, F., Improta, S., Belluomini, G., Cortesi, C., Turi, B., 1971. University of Rome Carbon-14 dates IX. Radiocarbon 13, 395-411.

Andersen, K. K., Svensson, A., Johnsen, S. J., Rasmussen, S. O., Bigler, M., Röthlisberger, R., Ruth, U., Siggaard-Andersen, M. L., Peder Steffensen, J., Dahl-Jensen, D., et al., 2006. The Greenland ice core chronology 2005, 15-42ka. Part 1: Constructing the time scale. Quaternary Science Reviews 25 (23), 3246-3257.

Andrews, J. T., Geirsdóttir, A., Hardardóttir, J., Principato, S., Grönvold, K., 
Kristjansdóttir, G. B., Helgadóttir, G., Drexler, J., Sveinbjörnsdóttir, A., 2002. Distribution, sediment magnetism and geochemistry of the Saksunarvatn (10 $18060 \mathrm{cal}$. yr BP) tephra in marine, lake, and terrestrial sediments, northwest Iceland. Journal of Quaternary Science 17 (8), 731-745.

Andronico, D., Calderoni, G., Cioni, R., Sbrana, A., Sulpizio, R., Santacroce, R., 1995. Geological map of Somma-Vesuvius Volcano. Periodico di Mineralogia $64,77-78$.

Birks, H. H., Gulliksen, S., Haflidason, H., Mangerud, J., Possnert, G., 1996. New Radiocarbon Dates for the Vedde Ash and the Saksunarvatn Ash from Western Norway. Quaternary Research 45 (2), 119-127.

Björck, J., Wastegård, S., 1999. Climate oscillations and tephrochronology in eastern middle Sweden during the last glacial-interglacial transition. Journal of Quaternary Science 14 (5), 399-410.

Blaauw, M., Christen, J. A., 2005. Radiocarbon peat chronologies and environmental change. Journal of the Royal Statistical Society Series C-Applied Statistics 54, 805-816.

Blockley, S. P. E., Lane, C. S., Lotter, A. F., Pollard, A. M., 2007. Evidence for the presence of the Vedde Ash in Central Europe. Quaternary Science Reviews 26 (25-28), 3030-3036.

Bourne, A. J., Lowe, J. J., Trincardi, F., Asioli, A., Blockley, S. P. E., Wulf, S., Matthews, I. P., Piva, A., Vigliotti, L., 2010. Distal tephra record for the last ca 105,000 years from core PRAD 1-2 in the central Adriatic Sea: implications for marine tephrostratigraphy. Quaternary Science Reviews 29 (23-24), 3079-3094.

Bramham-Law, C. W. F., Theuerkauf, M., Lane, C. S., Mangerud, J., 2013. New findings regarding the Saksunarvatn Ash in Germany. Journal of Quaternary Science 28 (3), 248-257.

Brauer, A., Endres, C., Negendank, J. F. W., 1999. Lateglacial calendar year chronology based on annually laminated sediments from Lake Meerfelder Maar, Germany. Quaternary International 61 (1), 17-25.

Bronk Ramsey, C., 2008. Deposition models for chronological records. Quaternary Science Reviews 27 (1-2), 42-60.

Bronk Ramsey, C., 2009a. Bayesian analysis of radiocarbon dates. Radiocarbon 51 (1), 337-360.

Bronk Ramsey, C., 2009b. Dealing with outliers and offsets in radiocarbon dating. Radiocarbon 51 (3), 1023-1045.

Bronk Ramsey, C., Albert, P., Blockley, S., Hardiman, M., Lane, C., Macleod, A., Matthews, I. P., Muscheler, R., Palmer, A., Staff, R. A., 2014a. Integrating timescales with time-transfer functions: a practical approach for an INTIMATE database. Quaternary Science Reviews submitted.

Bronk Ramsey, C., Housley, R. A., Lane, C., Smith, V. C., Pollard, A. M., 2014b. The RESET database and associated analytical tools. Quaternary Science Reviews submitted.

Bronk Ramsey, C., Lee, S., 2013. Recent and Planned Developments of the Program OxCal. Radiocarbon 55 (2-3), 720-730. 
Brown, R., Orsi, G., de Vita, S., 2008. New insights into Late Pleistocene explosive volcanic activity and caldera formation on Ischia (southern Italy). Bulletin of Volcanology 70 (5), 583-603.

Buccheri, G., Bertoldo, M., Coppa, M., Munno, R., Pennetta, M., Siani, G., Valente, A., Vecchione, C., 2002a. Evoluzione sedimentaria e paleoclimatologia tardo-quaternaria della scarpata continentale del Golfo di Policastro (Mar Tirreno meridionale). Bollettino della Società Geologica Italiana $121(2), 187-210$.

Buccheri, G., Capretto, G., Donato, D. V., Esposito, P., Ferruzza, G., Pescatore, T., Ermolli, R. E., Senatore, M. R., Sprovieri, M., Bertoldo, M., Carella, D., Madonia, G., 2002b. A high resolution record of the last deglaciation in the southern Tyrrhenian Sea: environmental and climatic evolution. Marine Geology 186 (3-4), 447-470.

Cassignol, C., Gillot, P. Y., 1982. Range and effectiveness of unspiked potassium-argon dating : experimental ground work and application. In: Odin, G. (Ed.), Numerical Dating in Stratigraphy. Wiley, New York, p. 160.

Civetta, L., Cornette, Y., Gillot, P. Y., Orsi, G., 1988. The eruptive history of Pantelleria (Sicily channel) in the last 50 ka. Bulletin of Volcanology 50 (1), $47-57$.

Cornette, Y., Crisci, G. M., Gillot, P. Y., Orsi, G., 1983. Recent volcanic history of Pantelleria: a new interpretation. Journal of Volcanology and Geothermal Research 17 (1-4), 361-373.

Costa, A., Folch, A., Macedonio, G., Giaccio, B., Isaia, R., Smith, V., 2012. Quantifying volcanic ash dispersal and impact of the Campanian Ignimbrite super-eruption. Geophysical Research Letters 39 (10).

Davies, S. M., Abbott, P. M., Pearce, N. J. G., Wastegård, S., Blockley, S. P. E., 2012. Integrating the INTIMATE records using tephrochronology: rising to the challenge. Quaternary Science Reviews 36, 11-27.

Davies, S. M., Hoek, W. Z., Bohncke, S. J. P., Lowe, J. J., O'Donnell, S. P., Turney, C. S. M., 2005. Detection of Lateglacial distal tephra layers in the Netherlands. Boreas 34 (2), 123-135.

Davies, S. M., Turney, C. S. M., Lowe, J. J., 2001. Identification and significance of a visible, basalt-rich Vedde Ash layer in a Late-glacial sequence on the Isle of Skye, Inner Hebrides, Scotland. Journal of Quaternary Science $16(2), 99-104$.

Davies, S. M., Wastegård, S., Wohlfarth, B., 2003. Extending the limits of the Borrobol Tephra to Scandinavia and detection of new early Holocene tephras. Quaternary Research 59 (3), 345-352.

Davies, S. M., Wohlfarth, B., Wastegård, S., Andersson, M., Blockley, S. P. E., Possnert, G., 2004. Were there two Borrobol Tephras during the early Lateglacial period: implications for tephrochronology? Quaternary Science Reviews 23 (5-6), 581-589.

Deino, A. L., Orsi, G., de Vita, S., Piochi, M., 2004. The age of the Neapolitan Yellow Tuff caldera-forming eruption (Campi Flegrei caldera Italy) assessed 
by $40 \mathrm{Ar} / 39 \mathrm{Ar}$ dating method. Journal of Volcanology and Geothermal Research 133 (1-4), 157-170.

Di Vito, M. A., Isaia, R., Orsi, G., Southon, J., de Vita, S., D'Antonio, M., Pappalardo, L., Piochi, M., 1999. Volcanism and deformation since 12,000 years at the Campi Flegrei caldera (Italy). Journal of Volcanology and Geothermal Research 91 (2-4), 221-246.

Di Vito, M. A., Sulpizio, R., Zanchetta, G., D'Orazio, M., 2008. The late Pleistocene pyroclastic deposits of the Campanian Plain: New insights into the explosive activity of Neapolitan volcanoes. Journal of Volcanology and Geothermal Research 177 (1), 19-48.

Druitt, T. M., Mellors, R. A., Pyle, D. M., Sparks, S. R. J., 1989. Explosive volcanism on Santorini, Greece. Geological Magazine 126, 95-126.

Dugmore, A. J., Newton, A. J., 1997. Holocene tephra layers in the Faroe Islands. Frodskaparrit 45, 141-154.

Endres, C., 1997. Warvenchronologie und radiokarbondatierungen an holozaènen und spaètglazialen sedimenten des meerfelder maares. Unpublished $\mathrm{PhD}$ thesis, Universitaèt Potsdam, Germany, 1-98.

Eriksen, U., Friedrich, W. L., Tauber, H., Heinemeier, J., Rud, N., Thomsen, M. S., Buchardt, B., 1990. The stronghyle caldera: geological palaeontological and stable isotope evidence from radiocarbon dated stromatolites from Santorini. In: Hardy, D. A. (Ed.), Thera and the Aegean World III. The Thera Foundation, London, pp. 130-150.

Finsinger, W., Belis, C., Blockley, S. P. E., Eicher, U., Leuenberger, M., Lotter, A. F., Ammann, B., 2008. Temporal patterns in lacustrine stable isotopes as evidence for climate change during the late glacial in the Southern European Alps. Journal of Paleolimnology 40 (3), 885-895.

Gillot, P.-Y., Chiesa, S., Pasquare, G., Vezzoli, L., 1982. ¡33,000-yr K-Ar dating of the volcano-tectonic horst of the Isle of Ischia, Gulf of Naples. Nature 299 (5880), 242-245.

Hajdas, I., Ivy, S. D., Beer, J., Bonani, G., Imboden, D., Lotter, A. F., Sturm, M., Suter, M., 1993. Ams Radiocarbon Dating and Varve Chronology of Lake Soppensee - 6000 to 12000 C-14 Years Bp. Climate Dynamics 9 (3), 107-116.

Hajdas, I., Zolitschka, B., Ivy-Ochs, S. D., Beer, J., Bonani, G., Leroy, S. A. G., Negendank, J. W., Ramrath, M., Suter, M., 1995. AMS radiocarbon dating of annually laminated sediments from lake Holzmaar, Germany. Quaternary Science Reviews 14 (2), 137-143.

Hardiman, J. C., 1999. Deep sea tephra from Nisyros Island, eastern Aegean Sea, Greece. Geological Society, London, Special Publications 161 (1), 6988.

Housley, R. A., MacLeod, A., Nalepka, D., Jurochnik, A., Masojc, M., Davies, L., Lincoln, P. C., Ramsey, C. B., Gamble, C. S., Lowe, J. J., 2013. Tephrostratigraphy of a Lateglacial lake sediment sequence at Wegliny, southwest Poland. Quaternary Science Reviews 77, 4-18.

Hughen, K. A., Baillie, M. G. L., Bard, E., Beck, J. W., Bertrand, C. J. H., 
Blackwell, P. G., Buck, C. E., Burr, G. S., Cutler, K. B., Damon, P. E., Edwards, R. L., Fairbanks, R. G., Friedrich, M., Guilderson, T. P., Kromer, B., McCormac, G., Manning, S., Bronk Ramsey, C., Reimer, P. J., Reimer, R. W., Remmele, S., Southon, J. R., Stuiver, M., Talamo, S., Taylor, F. W., van der Plicht, J., Weyhenmeyer, C. E., 2004. Marine04 marine radiocarbon age calibration, 0-26 cal kyr BP. Radiocarbon 46 (3), 1059-1086.

Karkanas, P., White, D.and Lane, C. S., Cullen, V. L.and Stringer, C., Davies, S. W. G., Smith, V. C., Ntinou, M., Tsartsidou, G., KyparissiApostolika, N., 2014. Tephra chronostratigraphy and climatic events between the MIS6/5 transition and the beginning of MIS3 in Theopetra Cave, central Greece. Quaternary Science Reviews this issue.

Kraml, M., 1997. 40Ar/39Ar-Datierungen an distalen marinen Tephren des jung-quartären mediterranen Vulkanismus. Ph.D. thesis, Albert-LudwigsUniversität, Freiburg.

Lane, C. S., Andric, M., Cullen, V. L., Blockley, S. P. E., 2011a. The occurrence of distal Icelandic and Italian tephra in the Lateglacial of Lake Bled, Slovenia. Quaternary Science Reviews 30 (9-10), 1013-1018.

Lane, C. S., Blockley, S. P. E., Bronk Ramsey, C., Lotter, A. F., 2011 b. Tephrochronology and absolute centennial scale synchronisation of European and Greenland records for the last glacial to interglacial transition: A case study of Soppensee and NGRIP. Quaternary International 246 (1-2), $145-156$.

Lane, C. S., Blockley, S. P. E., Mangerud, J., Smith, V. C., Lohne, O. S., Tomlinson, E. L., Matthews, I. P., Lotter, A. F., 2012a. Was the 12.1 ka Icelandic Vedde Ash one of a kind? Quaternary Science Reviews 33, 87-99.

Lane, C. S., Brauer, A., Blockley, S. P. E., Dulski, P., 2013. Volcanic ash reveals time-transgressive abrupt climate change during the Younger Dryas. Geology 41 (12), 1251-1254.

Lane, C. S., Brauer, A., Blockley, S. P. E., Smith, V. C., Tomlinson, E. L., 2014. The Late Quaternary tephrostratigraphy of annually laminated Meerfelder Maar, Germany. Quaternary Science Reviews this issue.

Lane, C. S., Klerk, D. P., Cullen, V. L., 2012b. A tephrochronology for the Lateglacial palynological record of the Endinger Bruch (Vorpommern, north-east Germany). Journal of Quaternary Science 27 (2), 141-149.

Larsen, G., 2010. Katla: Tephrochronology and Eruption History. In: Schomacker, A., Krßger, J., Kjr, K. H. (Eds.), The Mürdalsjökull Ice Cap, Iceland. Glacial processes, sediments and landforms on an active volcano. Vol. 13 of Developments in Quaternary Sciences. Elsevier, Ch. 3, pp. 23-49.

Lee, S., Bronk Ramsey, C., Hardiman, M., 2013. Modeling the Age of the Cape Riva (Y-2) Tephra. Radiocarbon 55 (3-4).

Limburg, M. E., Varekamp, J. C., 1991. Young pumice deposits on Nisyros, Greece. Bulletin of Volcanology 54 (1), 68-77.

Lind, E. M., Wastegård, S., 2011. Tephra horizons contemporary with short early Holocene climate fluctuations: New results from the Faroe Islands. Quaternary International 246 (1-2), 157-167. 
Lohne, O. y. S., Mangerud, J., Birks, H. H., 2013. Precise $14 \mathrm{C}$ ages of the Vedde and Saksunarvatn ashes and the Younger Dryas boundaries from western Norway and their comparison with the Greenland Ice Core (GICC05) chronology. Journal of Quaternary Science 28 (5), 490-500.

Lotter, A. F., Zbinden, H., 1989. Late-Glacial Pollen Analysis, Oxygen-Isotope Record, and Radiocarbon Stratigraphy from Rotsee (Lucerne), Central Swiss Plateau. Eclogae Geologicae Helvetiae 82 (1), 191-202.

Lowe, J., Barton, N., Blockley, S., Bronk Ramsey, C., Cullen, V. L., Davies, W., Gamble, C., Grant, K., Hardiman, M., Housley, R., Lane, C. S., Lee, S., Lewis, M., MacLeod, A., Menzies, M., Mueller, W., Pollard, M., Price, C., Roberts, A. P., Rohling, E. J., Satow, C., Smith, V. C., Stringer, C. B., Tomlinson, E. L., White, D., Albert, P., Arienzo, I., Barker, G., Boric, S., Carandente, A., Civetta, L., Ferrier, C., Guadelli, J.-L., Karkanas, P., Koumouzelis, M., Mueller, U. C., Orsi, G., Pross, J., Rosi, M., ShalamanovKorobar, L., Sirakov, N., Tzedakis, P. C., 2012. Volcanic ash layers illuminate the resilience of Neanderthals and early modern humans to natural hazards. Proceedings of the National Academy of Sciences of the United States of America 109 (34), 13532-13537.

Lowe, J. J., Turney, C. S. M., 1997. Vedde Ash layer discovered in a small lake basin on the Scottish mainland. Journal of the Geological Society, London 154 (4), 605-612.

Magny, M., de Beaulieu, J.-L., Drescher-Schneider, R., Vannière, B., WalterSimonnet, A.-V., Millet, L., Bossuet, G., Peyron, O., 2006. Climatic oscillations in central Italy during the Last Glacial-Holocene transition: the record from Lake Accesa. Journal of Quaternary Science 21 (4), 311-320.

Mahood, G., Hildreth, W., 1986. Geology of the peralkaline volcano at Pantelleria, Strait of Sicily. Bulletin of Volcanology 48 (2), 143-172.

Margari, V., Gibbard, P. L., Bryant, C. L., Tzedakis, P. C., 2009. Character of vegetational and environmental changes in southern Europe during the last glacial period; evidence from Lesvos Island, Greece. Quaternary Science Reviews 28 (13), 1317-1339.

Matthews, I. P., Birks, H. H., Bourne, A. J., Brooks, S. J., Lowe, J. J., MacLeod, A., Pyne-O'Donnell, S. D. F., 2011. New age estimates and climatostratigraphic correlations for the Borrobol and Penifiler Tephras: evidence from Abernethy Forest, Scotland. Journal of Quaternary Science 26 (3), 247-252.

Muller, U. C., Pross, J., Tzedakis, P. C., Gamble, C., Kotthoff, U., Schmiedl, G., Wulf, S., Christanis, K., 2011. The role of climate in the spread of modern humans into Europe. Quaternary Science Reviews 30 (3-4), 273279 .

Norddahl, H., Haflidason, H., 1992. The Skogar tephra, a Younger Dryas marker in north Iceland. Boreas 21 (1), 23-41.

Pappalardo, L., Civetta, L., D'Antonio, M., Deino, A., Vito, D. M., Orsi, G., Carandente, A., de Vita, S., Isaia, R., Piochi, M., 1999. Chemical and Sr-isotopical evolution of the Phlegraean magmatic system before the Cam- 
panian Ignimbrite and the Neapolitan Yellow Tuff eruptions. Journal of Volcanology and Geothermal Research 91 (2-4), 141-166.

Pilcher, J., Bradley, R., Francus, P., Anderson, L., 2005. A Holocene tephra record from the Lofoten Islands, Arctic Norway. Boreas 34 (2), 136-0.

Pyle, D. M., Margari, V., 2009. Reply: Correlation of a widespread Pleistocene tephra marker from the Nisyros-Yali volcanic complex, Greece. Journal of Volcanology and Geothermal Research 181 (3-4), 251-254.

Pyle, D. M., Ricketts, G. D., Margari, V., van Andel, T. H., Sinitsyn, A. A., Praslov, N. D., Lisitsyn, S., 2006. Wide dispersal and deposition of distal tephra during the Pleistocene Campanian Ignimbrite/Y5 eruption, Italy. Quaternary Science Reviews 25 (21-22), 2713-2728.

Pyne-O'Donnell, S. D. F., 2007. Three new distal tephras in sediments spanning the Last Glacial-Interglacial Transition in Scotland. Journal of Quaternary Science 22 (6), 559-570.

Pyne-O'Donnell, S. D. F., Blockley, S. P. E., Turney, C. S. M., Lowe, J. J., 2008. Distal volcanic ash layers in the Lateglacial Interstadial (GI-1): problems of stratigraphic discrimination. Quaternary Science Reviews 27 (1-2), $72-84$.

Ranner, P. H., Allen, J. R. M., Huntley, B., 2005. A new early Holocene cryptotephra from northwest Scotland. Journal of Quaternary Science 20 (3), 201-208.

Rasmussen, S. O., Andersen, K. K., Svensson, A. M., Steffensen, J. P., Vinther, B. M., Clausen, H. B., Siggaard-Andersen, M. L., Johnsen, S. J., Larsen, L. B., Dahl-Jensen, D., Bigler, M., Röthlisberger, R., Fischer, H., GotoAzuma, K., Hansson, M. E., Ruth, U., 2006. A new Greenland ice core chronology for the last glacial termination. Journal of Geophysical Research 111.

Rasmussen, S. O., Bigler, M., Blockley, S. P. E., Blunier, T., Buchardt, S. L., Clausen, H. B., Cvijanovic, I., Dahl-Jensen, D., Johnsen, S. J., Fischer, H., Gkinis, V., Guillevic, M., Hoek, W. Z., Lowe, J. J., Pedro, J., Popp, T., Seierstad, I. K., Steffensen, J. P., Svensson, A. M., Vallelonga, P., Vinther, B. M., Walkerv, M. J. C., Wheatley, J. J., Winstrup, M., 2014. A stratigraphic framework for naming and robust correlation of abrupt climatic changes during the last glacial period based on three synchronized Greenland ice core records. Quaternary Science Reviews submitted.

Rasmussen, S. O., Seierstad, I. K., Andersen, K. K., Bigler, M., Dahl-Jensen, D., Johnsen, S. J., 2008. Synchronization of the NGRIP, GRIP, and GISP2 ice cores across MIS 2 and palaeoclimatic implications. Quaternary Science Reviews 27 (1-2), 18-28.

Reimer, P. J., Baillie, M. G. L., Bard, E., Bayliss, A., Beck, J. W., Bertrand, C. J. H., Blackwell, P. G., Buck, C. E., Burr, G. S., Cutler, K. B., Damon, P. E., Edwards, R. L., Fairbanks, R. G., Friedrich, M., Guilderson, T. P., Hogg, A. G., Hughen, K. A., Kromer, B., McCormac, G., Manning, S., Bronk Ramsey, C., Reimer, R. W., Remmele, S., Southon, J. R., Stuiver, M., Talamo, S., Taylor, F. W., van der Plicht, J., Weyhenmeyer, C. E., 
2004. IntCal04 terrestrial radiocarbon age calibration, 0-26 cal kyr BP. Radiocarbon 46 (3), 1029-1058.

Reimer, P. J., Baillie, M. G. L., Bard, E., Bayliss, A., Beck, J. W., Blackwell, P. G., Bronk Ramsey, C., Buck, C. E., Burr, G. S., Edwards, R. L., Friedrich, M., Grootes, P. M., Guilderson, T. P., Hajdas, I., Heaton, T. J., Hogg, A. G., Hughen, K. A., Kaiser, K. F., Kromer, B., McCormac, F. G., Manning, S. W., Reimer, R. W., Richards, D. A., Southon, J. R., Talamo, S., Turney, C. S. M., van der Plicht, J., Weyhenmeyer, C. E., 2009. IntCal09 and Marine09 radiocarbon age calibration curves, 0-50,000 years cal BP. Radiocarbon 51 (4), 1111-1150.

Reimer, P. J., Bard, E., Bayliss, A., Beck, J. W., Blackwell, P. G., Bronk Ramsey, C., Grootes, P. M., Guilderson, T. P., Haflidason, H., Hajdas, I., Hatté, C., Heaton, T. J., Hoffmann, D. L., Hogg, A. G., Hughen, K. A., Kaiser, K. F., Kromer, B., Manning, S. W., Niu, M., Reimer, R. W., Richards, D. A., Scott, E. M., Southon, J. R., Staff, R. A., Turney, C. S. M., van der Plicht, J., 2013. IntCal13 and Marine13 Radiocarbon Age Calibration Curves 050,000 Years cal BP. Radiocarbon 55 (4), 1869-1887.

Riede, F., Bazely, O., Newton, A. J., Lane, C. S., 2011. A Laacher See-eruption supplement to Tephrabase: Investigating distal tephra fallout dynamics. Quaternary International 246 (1-2), 134-144.

Riede, F., Wheeler, J. M., 2009. Testing the "Laacher See hypothesis": tephra as dental abrasive. Journal of Archaeological Science 36 (10), 2384-2391.

Roeser, P. A., Franz, S. O., Litt, T., Ülgen, U. B., Hilgers, A., Wulf, S., Wennrich, V., Akçer Ön, S., Viehberg, F. A., Çağatay, N. M., et al., 2012. Lithostratigraphic and geochronological framework for the paleoenvironmental reconstruction of the last $36 \mathrm{ka} \mathrm{cal} \mathrm{BP}$ from a sediment record from Lake Iznik (NW Turkey). Quaternary International 274, 73-87.

Scaillet, S., Vita-Scaillet, G., Rotolo, S. G., 2013. Millennial-scale phase relationships between ice-core and Mediterranean marine records: insights from high-precision 40Ar/39Ar dating of the Green Tuff of Pantelleria, Sicily Strait. Quaternary Science Reviews 78, 141-154.

Scandone, R., Bellucci, F., Lirer, L., Rolandi, G., 1991. The structure of the Campanian Plain and the activity of the Neapolitan volcanoes (Italy). Journal of Volcanology and Geothermal Research 48 (1), 1-31.

Schmidt, R., van den Bogaard, C., Merkt, J., Müller, J., 2002. A new Lateglacial chronostratigraphic tephra marker for the south-eastern Alps: The Neapolitan Yellow Tuff (NYT) in Längsee (Austria) in the context of a regional biostratigraphy and palaeoclimate. Quaternary International 88, $45-56$.

Scholz, D., Hoffmann, D. L., 2011. StalAge - An algorithm designed for construction of speleothem age models. Quaternary Geochronology 6 (3-4), $369-382$.

Schoning, K., Klingberg, F., Wastegård, S., 2001. Marine conditions in central Sweden during the early Preboreal as inferred from a stable oxygen isotope gradient. Journal of Quaternary Science 16 (8), 785-794. 
Seymour, K. S. K. S., Christanis, K., Bouzinos, A., Papazisimou, S., Papatheodorou, G., Moran, E., Dénès, G., 2004. Tephrostratigraphy and tephrochronology in the Philippi peat basin, Macedonia, Northern Hellas (Greece). Quaternary International 121 (1), 53-65.

Shane, P., 2000. Tephrochronology: a New Zealand case study. Earth-Science Reviews 49 (1-4), 223-259.

Siani, G., Paterne, M., Arnold, M., Bard, E., Metivier, B., Tisnerat, N., Bassinot, F., 2000. Radiocarbon reservoir ages in the Mediterranean Sea and Black Sea. Radiocarbon 42, 271-280.

Siani, G., Paterne, M., Michel, E., Sulpizio, R., Sbrana, A., Arnold, M., Haddad, G., 2001. Mediterranean Sea Surface Radiocarbon Reservoir Age Changes Since the Last Glacial Maximum. Science 294 (5548), 1917-1920.

Siani, G., Sulpizio, R., Paterne, M., Sbrana, A., 2004. Tephrostratigraphy study for the last 18,000 14C years in a deep-sea sediment sequence for the South Adriatic. Quaternary Science Reviews 23 (23-24), 2485-2500.

Smith, V. C., Isaia, R., Pearce, N. J. G., 2011. Tephrostratigraphy and glass compositions of post-15 kyr Campi Flegrei eruptions: implications for eruption history and chronostratigraphic markers. Quaternary Science Reviews 30 (25-26), 3638-3660.

Svensson, A., Andersen, K. K., Bigler, M., Clausen, H. B., Dahl-Jensen, D., Davies, S., Johnsen, S. J., Muscheler, R., Parrenin, F., Rasmussen, S. O., et al., 2008. A 60000 year Greenland stratigraphic ice core chronology. Climate of the Past 4 (1), 47-57.

Svensson, A., Andersen, K. K., Bigler, M., Clausen, H. B., Dahl-Jensen, D., Davies, S. M., Johnsen, S. J., Muscheler, R., Rasmussen, S. O., Röthlisberger, R., Steffensen, J. P., Vinther, B. M., 2006. The Greenland Ice Core Chronology 2005, 15-42 ka. Part 2: comparison to other records. Quaternary Science Reviews 25 (23-24), 3258-3267.

Thordarson, T., Larsen, G., 2007. Volcanism in Iceland in historical time: Volcano types, eruption styles and eruptive history. Journal of Geodynamics 43 (1), 118-152.

Tomlinson, E. L., Albert, P. G., Wulf, S., Brown, R., Smith, V. C., Keller, J., Orsi, G., Bourne, A. J., Menzies, M. A., 2014. Age and geochemistry of tephra layers from Ischia, Italy: constraints from proximal-distal correlations with Lago Grande di Monticchio. Journal of volcanology and Geothermal Research in press.

Tomlinson, E. L., Arienzo, I., Civetta, L., Wulf, S., Smith, V. C., Hardiman, M., Lane, C. S., Carandente, A., Orsi, G., Rosi, M., Muller, W., Menzies, M. A., 2012a. Geochemistry of the Phlegraean Fields (Italy) proximal sources for major Mediterranean tephras: Implications for the dispersal of Plinian and co-ignimbritic components of explosive eruptions. Geochimica et Cosmochimica Acta 93, 102-128.

Tomlinson, E. L., Kinvig, H. S., Smith, V. C., Blundy, J. D., Gottsmann, J., Muller, W., Menzies, M. A., 2012b. The Upper and Lower Nisyros Pumices: Revisions to the Mediterranean tephrostratigraphic record based on micron- 
beam glass geochemistry. Journal of Volcanology and Geothermal Research 243-244, 69-80.

Tomlinson, E. L., Thordarson, T., Lane, C. S., Smith, V. C., Manning, C. J., Muller, W., Menzies, M. A., 2012c. Petrogenesis of the Sólheimar ignimbrite (Katla, Iceland): Implications for tephrostratigraphy. Geochimica et Cosmochimica Acta 86, 318-337.

Turney, C. S. M., Burg, V. D. K., Wastegård, S., Davies, S. M., Whitehouse, N. J., Pilcher, J. R., Callaghan, C., 2006. North European last glacialinterglacial transition (LGIT; 15-9 ka) tephrochronology: extended limits and new events. Journal of Quaternary Science 21 (4), 335-345.

Turney, C. S. M., Harkness, D. D., Lowe, J. J., 1997. The use of microtephra horizons to correlate Late-glacial lake sediment successions in Scotland. Journal of Quaternary Science 12 (6), 525-531.

Turney, C. S. M., Lowe, J. J., Wastegård, S., Cooper, R., Roberts, S. J., 2001. The development of a tephrochronological framework for the last glacial-Holocene transition in NW Europe. In: Juvigne, E. H., Raynal, J.P. (Eds.), Tephras: Chronology, Archaeology. Vol. 1. Dossiers de l'ArchéoLogis, Haute-Loire, pp. 101-109.

van den Bogaard, P., 1995. 40Ar 39Ar ages of sanidine phenocrysts from Laacher See Tephra (12,900 yr BP): Chronostratigraphic and petrological significance. Earth and Planetary Science Letters 133 (1-2), 163-174.

van den Bogaard, P., Schmincke, H. U., 1985. Laacher See Tephra: A widespread isochronous late Quaternary tephra layer in Central and Northern Europe. Geological Society of America Bulletin 96 (12), 1554-1571.

Vespa, M., Keller, J., Gertisser, R., 2006. Interplinian explosive activity of Santorini volcano (Greece) during the past 150,000 years. Journal of Volcanology and Geothermal Research 153 (3-4), 262-286.

Vezzoli, L., 1988. X. Island of Ischia. Quaderni de la Ricerca Scientifica. Vol. 114. Consiglio nazionale delle ricerche (CNR), Rome, Italy.

Vivo, D. B., Rolandi, G., Gans, P. B., Calvert, A., Bohrson, W. A., Spera, F. J., Belkin, H. E., 2001. New constraints on the pyroclastic eruptive history of the Campanian volcanic Plain (Italy). Mineralogy and Petrology 73 (1), $47-65$.

Wastegård, S., Bjorck, S., Grauert, M., Hannon, G. E., 2001. The Mjauvotn tephra and other Holocene tephra horizons from the Faroe Islands: a link between the Icelandic source region, the Nordic Seas, and the European continent. The Holocene 11 (1), 101-109.

Wastegård, S., Björck, S., Possnert, G., Wohlfarth, B., 1998. Evidence for the occurrence of Vedde Ash in Sweden: radiocarbon and calendar age estimates. Journal of Quaternary Science 13 (3), 271-274.

Wastegård, S., Wohlfarth, B., Subetto, D. A., Sapelko, T. V., 2000. Extending the known distribution of the Younger Dryas Vedde Ash into northwestern Russia. Journal of Quaternary Science 15 (6), 581-586.

Watts, W. A., Allen, J. R. M., Huntley, B., 1996. Vegetation history and palaeoclimate of the last glacial period at Lago Grande di Monticchio, south- 
ern Italy. Quaternary Science Reviews 15 (2), 133-153.

Wohlfarth, B., Blaauw, M., Davies, S. M., Andersson, M., Wastegård, S., Hormes, A., Possnert, G., 2006. Constraining the age of Lateglacial and early Holocene pollen zones and tephra horizons in southern Sweden with Bayesian probability methods. Journal of Quaternary Science 21 (4), 321334.

Wood, R., Douka, K., Boscato, P., Haesaerts, P., Sinitsyn, A., Higham, T. F. G., 2012. Testing the ABOx-SC method: Dating known-age charcoals associated with the Campanian Ignimbrite. Quaternary Geochronology 9, $16-26$.

Wulf, S., Brauer, A., Mingram, J., Zolitschka, B., Negendank, J. F. W., 2007. Distal tephras in the sediments of Monticchio maar lakes. In: Principe, C. (Ed.), Geologia del Monte Vulture. Bollettino della Società Geologica Italiana. Bollettino della Società Geologica Italiana, pp. 105-122.

Wulf, S., Keller, J., Paterne, M., Mingram, J., Lauterbach, S., Opitz, S., Sottili, G., Giaccio, B., Albert, P. G., Satow, C., Tomlinson, E. L., Viccaro, M., Brauer, A., 2012. The 100-133ka record of Italian explosive volcanism and revised tephrochronology of Lago Grande di Monticchio. Quaternary Science Reviews 58, 104-123.

Wulf, S., Kraml, M., Brauer, A., Keller, J., Negendank, J. F. W., 2004. Tephrochronology of the 100 ka lacustrine sediment record of Lago Grande di Monticchio (southern Italy). Quaternary International 122 (1), 7-30.

Wulf, S., Kraml, M., Keller, J., 2008. Towards a detailed distal tephrostratigraphy in the Central Mediterranean: the last 20,000 yrs record of Lago Grande di Monticchio. Journal of Volcanology and Geothermal Research $177,118-132$.

Zanchetta, G., Sulpizio, R., Giaccio, B., Siani, G., Paterne, M., Wulf, S., D'Orazio, M., 2008. The Y-3 tephra: A Last Glacial stratigraphic marker for the central Mediterranean basin. Journal of Volcanology and Geothermal Research 177 (1), 145-154.

Zolitschka, B., 1991. Absolute dating of late Quaternary lacustrine sediments by high resolution varve chronology. Hydrobiologia 214, 59-61.

Zolitschka, B., Negendank, J. F. W., Lottermoser, B. G., 1995. Sedimentological proof and dating of the Early Holocene volcanic eruption of Ulmener Maar (Vulkaneifel, Germany). Geologische Rundschau 84 (1), 213-219. 
Table 1

Main tephra layers which constitute the tephra lattice with the best estimates of eruption ages from the literature. For consistency all age uncertainties are quoted at $1 \sigma$ or equivalent.

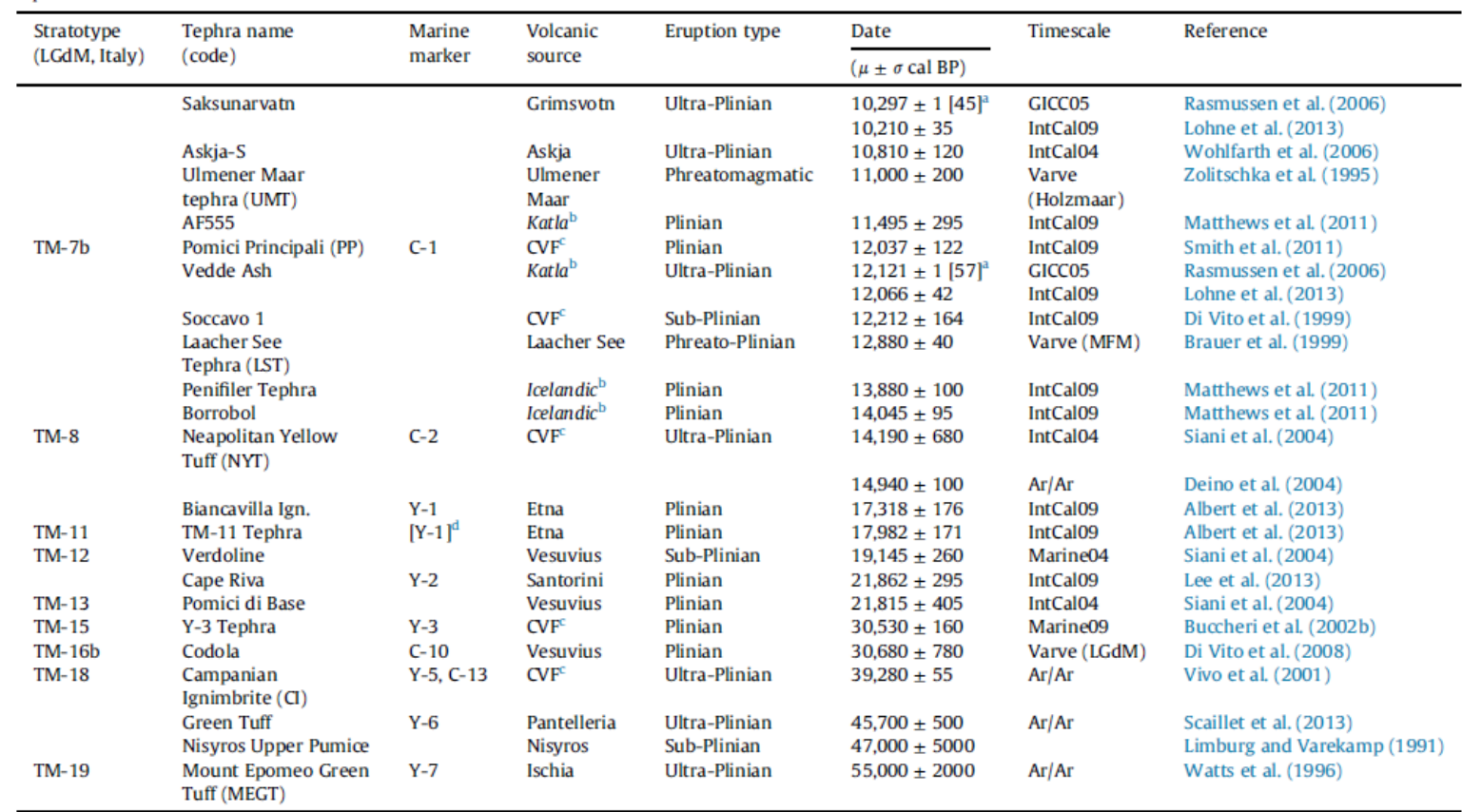

${ }^{a}$ Uncertainties in GICC05 are only against that timescale and do not include counting uncertainites: $1 \sigma$ equivalent error in timescale is given in square brackets.

bource inferred from chemical composition; tephra only known distally.

c Campanian Volvanic Field, Italy.

d The TM-11 tephra has been given the name Y-1 in the Central Adriatic.

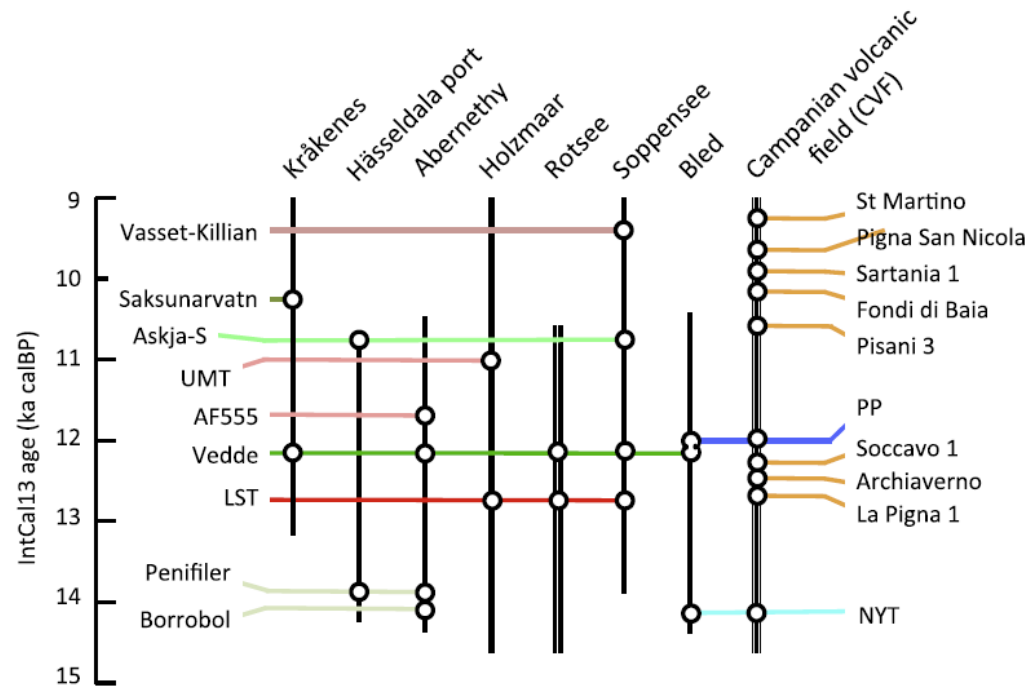

Fig. 1. Schematic for Bayesian model covering tephra layers in the range 9-15 ka cal BP (references given in the text). Note that, unlike the other specific records the CVF is a regional stratigraphic sequence compiled from many sites (Smith et al., 2011). Vertical lines represent records, horizontal lines correlated tephra layers and circles deposits of tephra within specific records. 


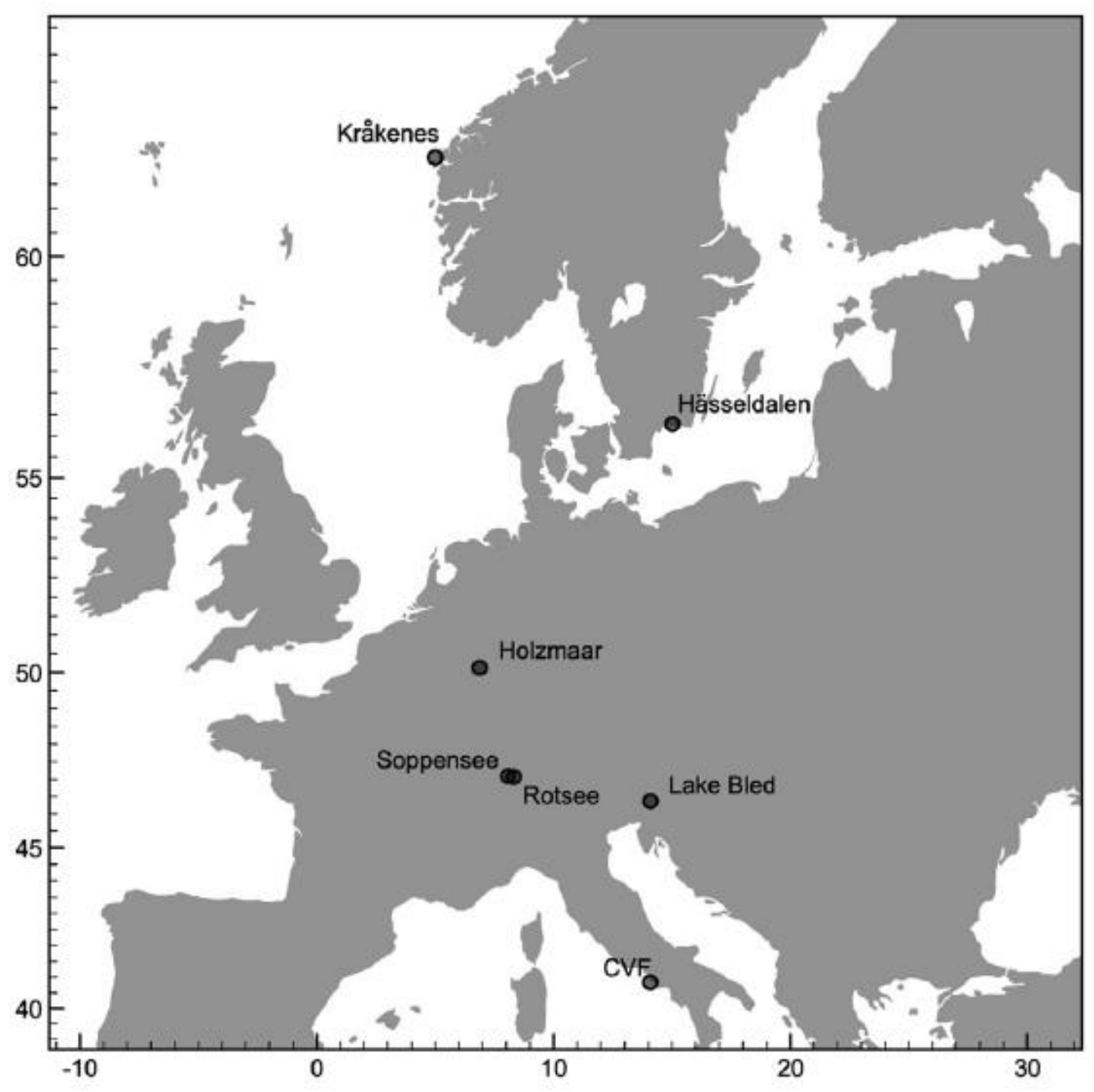

Fig. 2. Map showing the sites used in the Bayesian model covering tephra layers in the range $9-15 \mathrm{ka}$ cal $\mathrm{BP}$. 
Table 2

Results from the main 15-9 ka modelling exercise. Model 1 uses litho-stratigraphic boundaries and is slower to converge. Model 2 is simpler in that it allows the variability in the rigidity of each model to cater for changes in deposition rate. Both model outputs are shown here to see how robust the model output is to changes in model assumption. The results of Model 2 are to be preferred because they are less dependent on subjective choices.

\begin{tabular}{|c|c|c|c|c|}
\hline \multirow[t]{2}{*}{ Tephra } & \multicolumn{2}{|l|}{ Model 1} & \multicolumn{2}{|l|}{ Model 2} \\
\hline & $\begin{array}{l}\text { 95\% range } \\
\text { (cal BP) }\end{array}$ & $\begin{array}{l}\mu \pm \sigma \\
\text { (cal BP) }\end{array}$ & $\begin{array}{l}95 \% \text { range } \\
\text { (cal BP) }\end{array}$ & $\begin{array}{l}\mu \pm \sigma \\
\text { (cal BP) }\end{array}$ \\
\hline St Martino $^{1}$ & $9400-9033$ & $9215 \pm 90$ & $9400-9033$ & $9216 \pm 87$ \\
\hline $\begin{array}{r}\text { Pigna San } \\
\text { Nicola }^{1}\end{array}$ & $9529-9163$ & $9352 \pm 97$ & $9529-9164$ & $9352 \pm 97$ \\
\hline $\mathrm{VKT}^{2}$ & $9456-9229$ & $9339 \pm 56$ & $9486-9255$ & $9375 \pm 57$ \\
\hline Sartania $1^{1}$ & $9655-9495$ & $9564 \pm 40$ & $9655-9495$ & $9564 \pm 40$ \\
\hline Fondi di Baia ${ }^{1}$ & $9740-9507$ & $9624 \pm 102$ & 9739-9507 & $9622 \pm 87$ \\
\hline Saksunurvatn $^{3}$ & $10,254-10,095$ & $10,182 \pm 39$ & $10,257-10,056$ & $10,176 \pm 49$ \\
\hline Pisani $3^{1}$ & $11,068-10,553$ & $10,708 \pm 121$ & $11,068-10,550$ & $10,709 \pm 123$ \\
\hline Askja-S ${ }^{3}$ & $11,005-10,745$ & $10,879 \pm 65$ & $10,956-10,716$ & $10,830 \pm 57$ \\
\hline $\mathrm{UMT}^{3}$ & $11,397-10,914$ & $11,098 \pm 117$ & $11,400-10,907$ & $11,096 \pm 117$ \\
\hline AF555 ${ }^{3}$ & $11,705-11,181$ & $11,438 \pm 126$ & $11,721-11,231$ & $11,462 \pm 122$ \\
\hline $\mathrm{PP}^{3}$ & $12,105-11,929$ & $12,017 \pm 45$ & $12,091-11,850$ & $11,999 \pm 52$ \\
\hline Vedde $^{3}$ & $12,110-11,966$ & $12,040 \pm 35$ & $12,102-11,914$ & $12,023 \pm 43$ \\
\hline Soccavo $1^{3}$ & $12,390-12,025$ & $12,203 \pm 110$ & $12,391-12,017$ & $12,198 \pm 112$ \\
\hline Archiaverno $^{1}$ & $12,730-12,579$ & $12,665 \pm 42$ & $12,730-12,578$ & $12,666 \pm 41$ \\
\hline La Pigna $1^{1}$ & $13,055-12,749$ & $12,903 \pm 82$ & $13,055-12,749$ & $12,902 \pm 81$ \\
\hline $\mathrm{LST}^{3}$ & $12,980-12,890$ & $12,938 \pm 23$ & $12,979-12,889$ & $12,937 \pm 23$ \\
\hline Penifiler $^{3}$ & $14,045-13,795$ & $13,920 \pm 65$ & $14,063-13,808$ & $13,939 \pm 66$ \\
\hline Borrobol $^{3}$ & $14,171-13,991$ & $14,080 \pm 45$ & $14,190-14,003$ & $14,098 \pm 47$ \\
\hline $\mathrm{NYT}^{3}$ & $14,555-13,882$ & $14,186 \pm 169$ & $14,588-13,884$ & $14,194 \pm 172$ \\
\hline
\end{tabular}

Notes: ${ }^{1}$ Eruptions from the Campanian volcanic field (see Di Vito et al., 1999; Smith et al., 2011, for details); ${ }^{2}$ Vasset or Kilian volcano (VKT), Chaine des Puys, France (see Hajdas et al., 1993; Lane et al., 2011b, for details); ${ }^{3}$ See Table 1, for details of the eruptions and the text in Section 4 for references to the information included in the model for each tephra. 


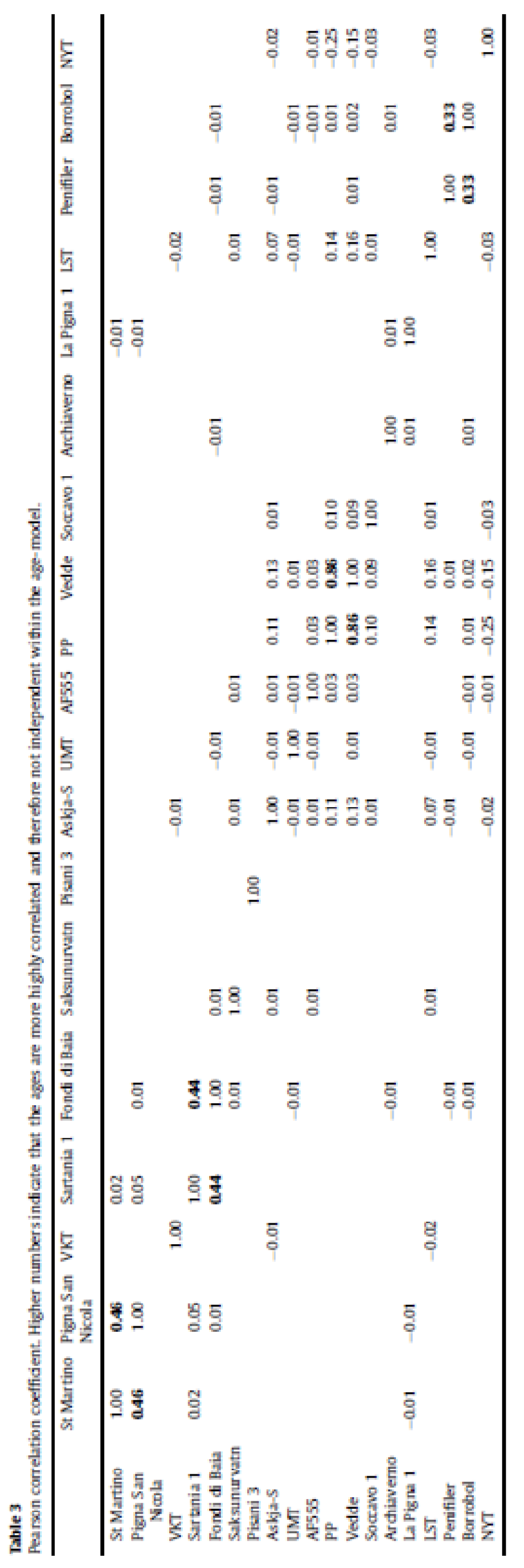




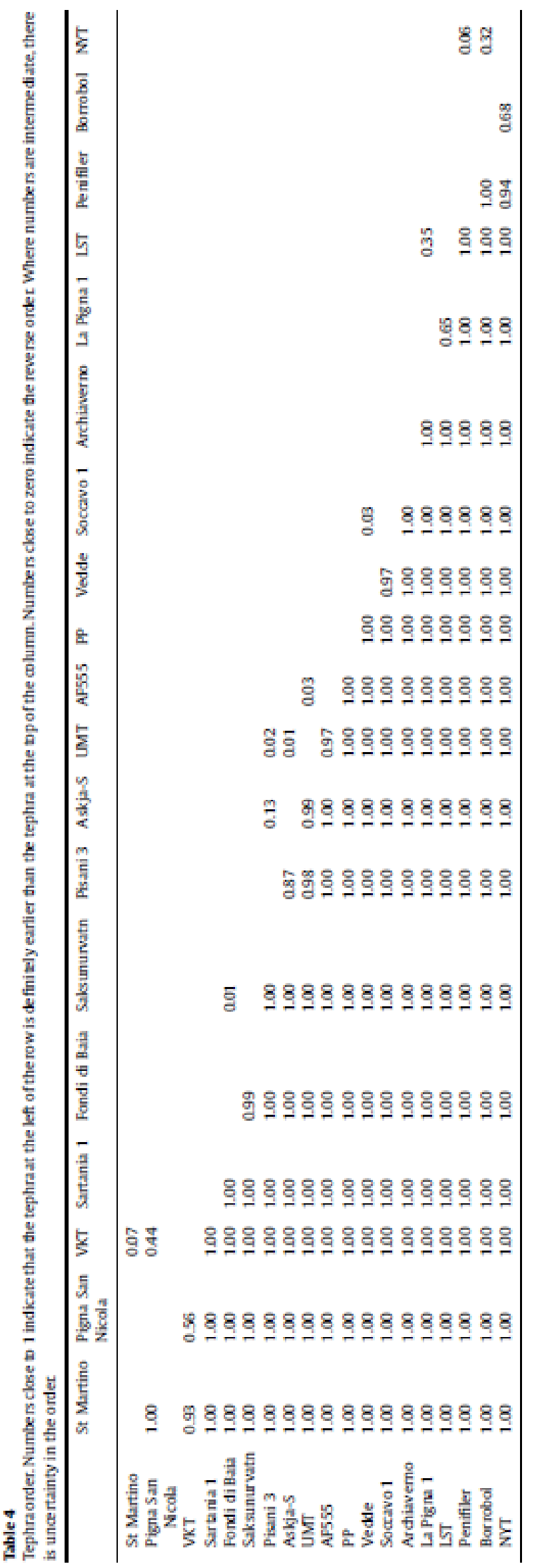




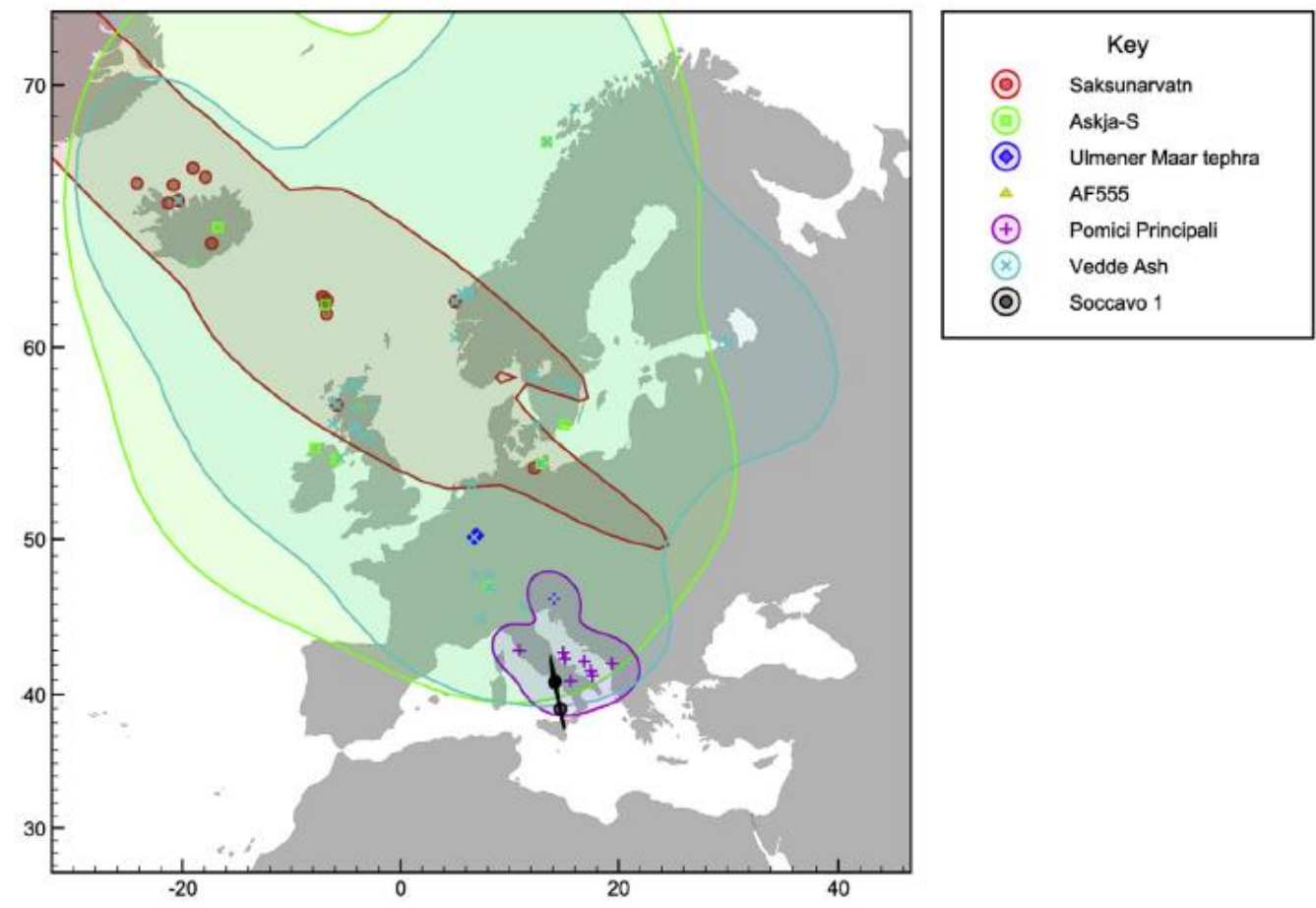

Fig. 3. Tephra dispersal recorded in the RESET database for eruptions in the range $10-12.5 \mathrm{ka}$ cal BP.

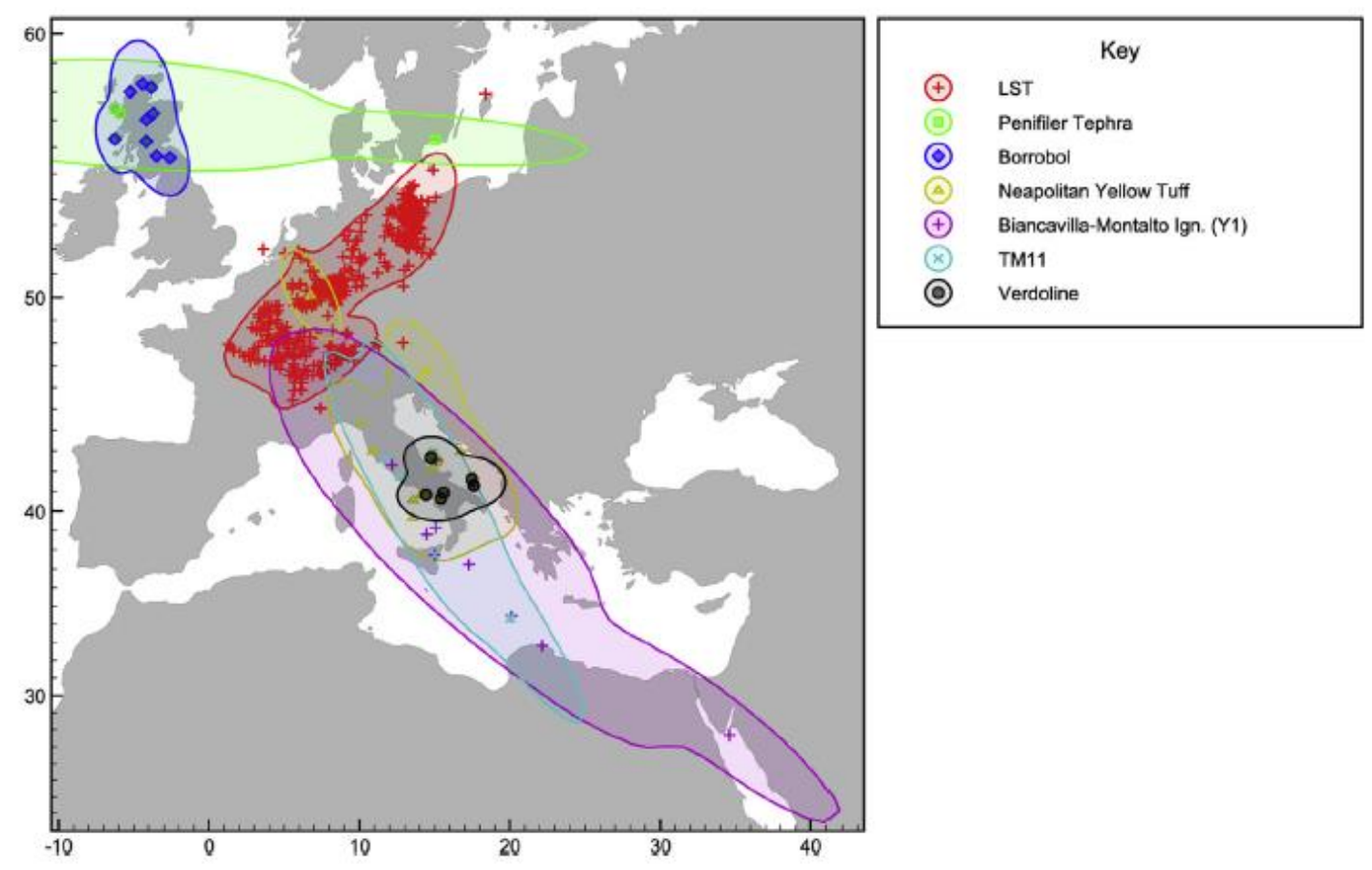

Fig. 4. Tephra dispersal recorded in the RESET database for euptions in the range $12.5-20 \mathrm{ka}$ cal BP. 


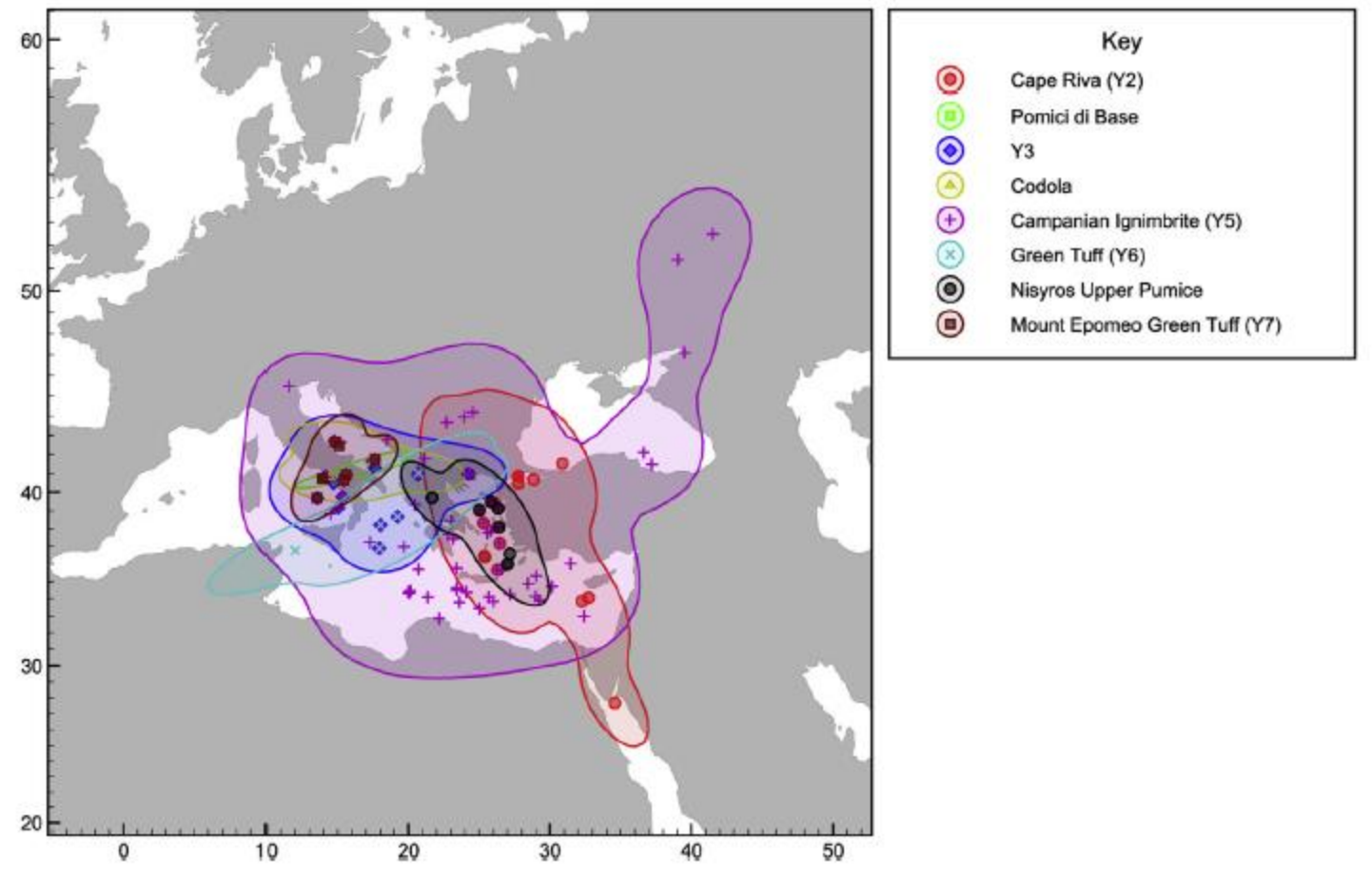

Fig 5. Tephra dispersal recorded in the RESET database for eruptions in the range 20-60 ka cal BP.

\section{Table 5}

Revised dates for the main units surrounding the Y-1 from mount Etna updated for IntCal13 (after Albert et al., 2013).

\begin{tabular}{lll}
\hline Unit name & $95 \%$ range (cal BP) & $\mu \pm \sigma(\mathrm{cal} \mathrm{BP})$ \\
\hline Biancavilla Ignimbrite & $17,605-17,065$ & $17,335 \pm 139$ \\
TM-11 & $18,349-17,870$ & $18,106 \pm 120$ \\
D2a Giarre & $18,501-18,051$ & $18,282 \pm 112$ \\
D1a Giarre & $18,818-18,550$ & $18,688 \pm 68$ \\
TM-12-1 & $19,839-19,421$ & $19,626 \pm 106$ \\
\hline
\end{tabular}


Table 6

Radiocarbon data from cores C106 (Buccheri et al., 2002b) and C45 (Buccheri et al., 2002a) in the Tyrrhenian Sea, which contain tephra layers from the Neapolitan volcanoes.

\begin{tabular}{lccc}
\hline Layer/Labcode & ${ }^{14} \mathrm{C}$ date $(\mathrm{BP})$ & Depth $(\mathrm{cm})$ & EF depth $(\mathrm{cm})$ \\
\hline Core C106 & & 0.0 & \\
Core top & & 55.5 & 0.0 \\
Vesuvius AD79 top & & 110.0 & 55.5 \\
Vesuvius AD79 bottom & $3470 \pm 40$ & 140.0 & 85.5 \\
GX-26471 & $5660 \pm 40$ & 200.0 & 145.5 \\
GX-26472 & $8160 \pm 70$ & 250.0 & 195.5 \\
GX-25380 & $9870 \pm 100$ & 310.0 & 255.5 \\
GX-25381 & $12,870 \pm 100$ & 370.0 & 315.5 \\
GX-25382 & $17,110 \pm 60$ & 470.0 & 415.5 \\
GX-26473 & & 565 & 510.5 \\
Y-3 top & & 579 & 510.5 \\
Y-3 bottom & $26,030 \pm 150$ & 583.0 & 514.5 \\
GX-26474 & & & \\
Core C45 & & 0.0 & 0.0 \\
Core top & & 18.0 & 18.0 \\
Vesuvius AD79 top & & 25.0 & 18.0 \\
Vesuvius AD79 bottom & $8500 \pm 50$ & 97.0 & 90.0 \\
& & 151.0 & 144.0 \\
Pomici Principale top & & 152.0 & 144.0 \\
Pomici Principale bottom & & 309.0 & 301.0 \\
& $19,490 \pm 100$ & 379.5 & 371.5 \\
Y-3 top & & 383.0 & 371.5 \\
Y-3 bottom & & 386.0 & 374.5 \\
& $25,570 \pm 110$ & 456.5 & 445.0 \\
CI top & & 460.0 & 445.0 \\
Cl bottom & & & \\
\hline
\end{tabular}


Table 7

Main tephra layers that make up the tephra lattice with their estimates updated (in bold) in this paper; all uncertainties are quoted at $1 \sigma$ for consistency.

\begin{tabular}{|c|c|c|c|c|c|c|c|}
\hline \multirow{2}{*}{$\begin{array}{l}\text { Stratotype } \\
\text { (LGdM, Italy) }\end{array}$} & \multirow[t]{2}{*}{ Tephra name (code) } & \multirow{2}{*}{$\begin{array}{l}\text { Marine } \\
\text { marker }\end{array}$} & \multirow{2}{*}{$\begin{array}{l}\text { Volcanic } \\
\text { source }\end{array}$} & \multirow[t]{2}{*}{ Eruption type } & \multirow{2}{*}{$\frac{\text { Date }}{(\mu \pm \sigma \text { cal BP })}$} & \multirow[t]{2}{*}{ Timescale } & \multirow[t]{2}{*}{ Reference } \\
\hline & & & & & & & \\
\hline & Saksunarvatn & & Grimsvotn & Ultra-Plinian & $10,297 \pm 1[45]^{2}$ & GICC05 & Rasmussen et al. (2006) \\
\hline & & & & & $10,176 \pm 49$ & IntCal13 & Lohne et al. (2013), this paper \\
\hline & Askja-S & & Askja & Ultra-Plinian & $10,830 \pm 57$ & IntCal13 & $\begin{array}{l}\text { Wohlfarth et al, (2006); Lane et al } \\
\text { (2011b), this paper }\end{array}$ \\
\hline & $\begin{array}{l}\text { Ulmener Maar } \\
\text { tephra }\end{array}$ & & $\begin{array}{l}\text { Ulmener } \\
\text { Maar }\end{array}$ & Phreatomagmatic & $11,096 \pm 117$ & IntCal13 & Zolitschka et al. (1995), this paper \\
\hline & AF555 & & Katla $a^{b}$ & Plinian & $11,462 \pm 122$ & IntCal13 & Matthews et al. (2011), this paper \\
\hline \multirow[t]{9}{*}{$\mathrm{TM}-7 \mathrm{~b}$} & Pomici Principali (PP) & $\mathrm{C}-1$ & $\mathrm{CVF}^{\mathrm{c}}$ & Plinian & $11,999 \pm 52$ & IntCal13 & $\begin{array}{l}\text { Smith et al. (2011); Lane et al. } \\
\text { (2011a), this paper }\end{array}$ \\
\hline & Vedde Ash & & Katla $a^{b}$ & Ultra-Plinian & $12,121 \pm 1[57]^{2}$ & GICC05 & Rasmussen et al. (2006) \\
\hline & & & & & $12,023 \pm 43$ & IntCal13 & $\begin{array}{l}\text { Lohne et al. (2013); Lotter and } \\
\text { Zbinden (1989); Hajdas et al. } \\
\text { (1993); Lane et al.(201 1b,a), } \\
\text { this paper }\end{array}$ \\
\hline & Soccavo 1 & & $\mathrm{CVF}^{\mathrm{C}}$ & Sub-Plinian & $12,198_{ \pm} 112$ & IntCal13 & Di Vito et al. (1999), this paper \\
\hline & Laacher See & & Laacher & Phreato-Plinian & $12,880 \pm 40$ & Varve (MFM) & Brauer et al. (1999) \\
\hline & Tephra (IST) & & See & & & & \\
\hline & & & & & $12,937 \pm 23$ & IntCal13 & $\begin{array}{l}\text { Zolitschka et al. (1995); Hajdas et al. } \\
\text { (1993); Lane et al. (2011b,a), } \\
\text { this paper }\end{array}$ \\
\hline & Penifiler Tephra & & Icelandic ${ }^{b}$ & Plinian & $13,939 \pm 66$ & IntCal13 & $\begin{array}{l}\text { Matthews et al. (2011); Wohlfarth } \\
\text { et al. (2006), this paper }\end{array}$ \\
\hline & Borrobol & & Icelandic $c^{b}$ & Plinian & $14,098 \pm 47$ & IntCal13 & Matthews et al. (2011), this paper \\
\hline \multirow[t]{3}{*}{ TM-8 } & $\begin{array}{l}\text { Neapolitan Yellow } \\
\text { Tuff (NYT) }\end{array}$ & $\mathrm{C}-2$ & $\mathrm{CVF}^{c}$ & Ultra-Plinian & $14,194 \pm 172$ & IntCal13 & Siani et al. (2004), this paper \\
\hline & & & & & $14,940 \pm 100$ & $\mathrm{Ar} / \mathrm{Ar}$ & Deino et al. (2004) \\
\hline & $\begin{array}{l}\text { Biancavilla-Montalto } \\
\text { Ign. }\end{array}$ & {$[\mathrm{Y}-1]$} & Etna & Plinian & $17,335 \pm 139$ & IntCal13 & Albert et al. (2013), this paper \\
\hline TM-11 & $\mathrm{TM}-11$ & {$[\mathrm{Y}-1]^{d}$} & Etna & Plinian & $18,106 \pm 120$ & IntCal13 & Albert et al. (2013), this paper \\
\hline \multirow[t]{2}{*}{ TM-12 } & Verdoline & & Vesuvius & Sub-Plinian & $19,226 \pm 104$ & IntCal13/Marine 13 & Siani et al. (2004), this paper \\
\hline & Cape Riva & $\mathrm{Y}-2$ & Santorini & Plinian & $22,024 \pm 321$ & IntCal13 & $\begin{array}{l}\text { Lee et al. (2013); Margari et al. } \\
\text { (2009), this paper }\end{array}$ \\
\hline TM-13 & Pomici di Base & & Vesuvius & Plinian & $22,081 \pm 173$ & IntCal13 & $\begin{array}{l}\text { Muller et al. (2011); Roeser } \\
\text { et al. (2012); Seymour et al. } \\
\text { (2004), this paper Siani et al. } \\
\text { (2004), this paper }\end{array}$ \\
\hline TM-15 & Y-3 Tephra & $\mathrm{Y}-3$ & $\mathrm{CVF}^{c}$ & Plinian & $29,059 \pm 178$ & IntCal13/Marine 13 & $\begin{array}{l}\text { Buccheri et al. (2002b,a); Albert } \\
\text { et al. (2014); Muller et al. (2011), } \\
\text { this paper }\end{array}$ \\
\hline \multirow[t]{2}{*}{$\mathrm{TM}-16 \mathrm{~b}$} & Codola & C-10 & Vesuvius & Plinian & $30,680 \pm 780$ & Varve (LGdM) & Di Vito et al. (2008) \\
\hline & & & & & $29,250 \pm 480$ & IntCal13 & Alessio et al. (1974), this paper \\
\hline \multirow[t]{4}{*}{ TM-18 } & $\begin{array}{l}\text { Campanian } \\
\text { Ignimbrite (Cl) }\end{array}$ & Y-5, C-13 & $\mathrm{CVF}^{\mathrm{C}}$ & Ultra-Plinian & $39,280 \pm 55$ & $\mathrm{Ar} / \mathrm{Ar}$ & Vivo et al. (2001) \\
\hline & & & & & $38,950 \pm 270$ & IntCal13 & Wood et al. (2012), this paper \\
\hline & Green Tuff & $Y-6$ & Pantelleria & Ultra-Plinian & $45,700 \pm 500$ & $\mathrm{Ar} / \mathrm{Ar}$ & Scaillet et al. (2013) \\
\hline & Nisyros Upper Pumice & & Nisyros & Sub-Plinian & $>50,400$ & & Karkanas et al. (2014) \\
\hline TM-19 & $\begin{array}{l}\text { Mount Epomeo Green } \\
\text { Tuff (MEGT) }\end{array}$ & $\mathrm{Y}-7$ & Ischia & Ultra-Plinian & $55,000 \pm 2000$ & $\mathrm{Ar} / \mathrm{Ar}$ & Watts et al. (1996) \\
\hline
\end{tabular}

${ }^{2}$ Errors against the GICCO5 dates do not include counting uncertainties in that timescale: $1 \sigma$ equivalent error in timescale is given in square brackets.

Source inferred from chemical composition; tephra only known distally.

c Campanian Volcanic Field, Italy.

d The TM-11 tephra has been given the name Y-1 in the Central Adriatic 